\title{
TÜRK KONUT MIMARISINDE TARIHSEL SÜREKLILIKLER: ORTA ASYA VE ANADOLU
}

\author{
KEMAL REHA KAVAS*
}

\section{GIRIŞ:}

\section{MIMARLIK TARİHI VE TÜRK KONUT MIMARISI' ${ }^{1}$}

Batı'daki tarihsel gelişimi içerisinde mimarlık tarihi, genellikle sanat tarihinin bir alt dalı olarak görülürken özellikle son elli yl içerisinde tarih yazımında ortaya çıkan kuramsal değişimler ile müstakil bir disiplin haline gelmiştir ${ }^{2}$. Mimarlık tarihi gibi antropoloji, sosyoloji, tarih vb. ilgili disiplinlerde paralel kuramsal dönüşümler çok genel bir çerçeve içerisinde Avrupa-merkezli bakış açılarının terk edilmesi ve sosyal bilimlerde tüm tarihsel ve coğrafi bağlamlara eşit önem verilmesi kapsamina alınabilir ${ }^{3}$.

20. yüzylda mimarlık tarihinin geçirdiği dönüşüm kilometre taşı sayllabilecek eserler üzerinden de gözlemlenebilir. En erken evrede Avrupa ve Kuzey Amerika dışndaki bölgeler "Doğu Sanat / Mimarlı̆ı" veya "Batıdısı Sanat," vb. genellemeler ile ayrı bir bölümde ele alınıyordu. Batı dışı kültürlerin kendi içerilerinde barındırdıkları özgünlükler ihmal ediliyordu. Aynca ABD'de defalarca yaymlanan ve dünya mimarlık tarihi alanında iz bırakan Bannister Fletcher'a ait "History of Architecture" adh eserde de olduğu gibi Batı sanat ve mimarlık tarihi kendi içerisindeki gelişimi içerisinde ve dünyanın diğer bölgelerinden bağımsız olarak anlatılmaktaydı ${ }^{4}$. Bu yaklaşımda diğer toplumların Batı ile kurduklanı

- Yrd. Doç. Dr., Akdeniz Üniversitesi Güzel Sanatlar Fakültesi Mimarhk Bölümü, Dumlupınar Bulvarı, 07058, Kampüs - Antalya/TÜRKIYE, e-posta: krkavas@gmail.com

' Bu makalede 13-14 Mays 2011 tarihlerinde Hoca Ahmet Yesevi Uluslararası Türk-Kazak Üniversitesi tarafindan Kazakistan'ın Türkistan kentinde düzenlenen IV. Uluslararası Türkoloji Kongresi'nde sunduğum ve Bildiriler Kitabı'nda yayınlanan "Tarihsel Süreklilikte Mimari ve Mekânsal Öğeler: Orta Asya ve Anadolu-Bat Toroslan Üzerine Notlar" başlıklı bildirimde ortaya konan kavramsal altyapı kullanılmaktadır.

${ }^{2}$ Alina Payne, "Architectural History and the History of Art: A Suspendend Dialogue," Joumal of the Society of Architectural Histonans, 58:3 (1999), s. 292-299

${ }^{3}$ Kemal R. Kavas, "Sanat Tarihi - Mimarlık Tarihi arasındaki Değişen İlişkilerin Sivil Konut Mimarisi Araşurmalan Bağlamında Değerlendirilmesi," Akdeniz Ünversitesi Güzel Sanatlar Fakültesi Akdeniz-Sanat Dergisi IV, s. 37-46.

${ }^{4}$ Bannister Fletcher, A Histony of Architecture on the Comparative Method, Scribner, New York, 1963. 
bağlantılar göz ardı edilmekteydi. Batı mimarlık tarihi kendi içinde yeterli bir kronolojik gelişime oturtulurdu. Gelişim ekseni yapı malzeme ve sistemlerindeki teknolojik gelişmişlik düzeyine göre kurgulanırdı ${ }^{5}$.

Ne var ki 20. yüzyllın ortalarından itibaren günümüzün sınıflandırmalarıyla "Doğu" ve "Batı" olarak tanımlanan kültürlerin tarih içerisinde keskin çizgiler ile ayrılmadıkları, günümüzde olduğu gibi geçmişte de birbirleriyle derin kültürel etkileşim halinde oldukları görülmüştür. Bu yazıya konu olan Anadolu konut mimarisinin tarihi için de basmakalıp Doğu - Batı ayrımı anlamsızlaşırken kültürlerarası etkileşimlerin yoğunluğu gün geçtikçe daha yakından görülmektedir. Mimarlık tarihini destekleyen arkeolojik bulgular, çeşitli kültürlerin yapı geleneklerinin zamandan ve mekândan bağımsız olarak sabit kalmadıklarını, aksine farkh kültürler ile etkileşim içerisinde ve zamana ve coğrafyaya da bağlı olarak yeni sentezler üretildiğini göstermektedir ${ }^{6}$.

Mimarlık tarihinin yönetici sınıflara has anıtsal yaplar seçkisine indirgenmesi ve bu seçkinin yapı sistem ve tekniklerindeki gelişim doğrultusunda tasnif edilmesi sonucunda ilgili mimari kültürler yeterli biçimde temsil edilememiştir. Anıtsal seçkilerden oluşan ve yapı tekniği gelişimi doğrultusunda kurgulanan tarih yazımı konut tarihinin oluşması önündeki temel engel halini almıştır ${ }^{7}$. Ayrıca konutun tarihini içeren kültürel tarih ile siyasi tarih arasında dönemleme açısından uyumsuzluk bulunmaktadır. Örneğin Anadolu'da tarih boyunca gözlenen üst yapıya dair idari değişiklikler buna paralel olarak halkın yaşam biçiminde gözle görülür değişimlere yol açmamıştır ${ }^{8}$.

\footnotetext{
${ }^{5}$ Eric Fernie, "Introduction: A History of Methods," Art History and Its Methods: A Critical Anthology, Phaidon, Hong Kong 1995, s. 10-21.

Bat Mimarłı tarihinin kendi içine kapalı bir evrim ile geliştiği düşüncesi felsefi olarak Hegel'in Zeitgeist (Çağın Ruhu) kavramına dayanmaktadır. Bat dışında kalan bölgelerin mimarileri tarihsel kronoloji dışarısında bırakılmakta ve bunlar tarihsel olarak görülmemektedir çünkü bu toplumlarda tarih boyunca sabit kalan ve zamana göre gelişim göstermeyen kültürel yapıların olduğu varsayılmaktadır.

${ }^{6}$ Ylddı Sey, "Giriş: Bir Sergi Hazırlamak," Tarihten Günümüze Anadolu'da Konut ve Yerleşme - T.C. Basbakanlk TOKT II. B.M. Insan Yerlesimleri - Habitat 1996 Konferans Bildiriler ve Sergi Kitabn (1996), s. xixxxiv.

${ }^{7}$ Uğur Tanyeli, "Anadolu'da Bizans, Osmanh Öncesi ve Osmanh Dönemlerinde Yerlešme ve Barnnma Düzeni," Tarihten Günümüze Anadolu'da Konut ve Yerleşme - T.C. Başbakanhk TOKI II. B.M. Insan Yerlegimlen - Habitat 1996 Konferanst Bildiriler ve Sergi Kitabı (1996), s. 405.

Tanyeli tarih boyunca sivil mimaride yalın mekan düzenlemeler ve mütevazi teknoloji kullanılmasından dolayı konut mimarisinde tektonik ve mekansal mimarlık tarihi analizlerinin olanaksızlaşığını vurgulamaktadır.

${ }^{8}$ Sey, a.g.m., s. xxi.
} 
Geçmişte konut tarihi yazımında görülen bu problemler günümüzde çözülmeye başlamıştır. Bilimsel yöntem uyarınca bir toplumun araşturılmasında varılacak en doğru sonucun niceliksel olarak yaygın olan özelliklerin tespit edilmesi ile mümkün olduğu artık kabul edilmekte$\operatorname{dir}^{9} . \mathrm{Bu}$ düşünceden hareketle toplumun büyük çoğunluğunu oluşturan sosyal tabakaların mimarisinde gene büyük bir çoğunluğu oluşturan konutların mimarisi önem kazanmıs ve mimarlık tarihindeki kuramsal dönüşümler sivil mimari araştırmalarını geliştirmiş ve zenginleştirmiştir.

Geçmişte kendisini Batı - Doğu dünyası ayrımı ve tarihsel toplumların yönetici sınıflarına has prestijli, anıtsal ve askeri yapılarla sınırlandıran mimarlık tarihi, günümüzde, geçmiş toplumlardaki tüm ekonomik-sosyal tabakalara özgü mekânsal özellikler ve yerleşme kalıplarının araştırılmasını hedeflemektedir. Örneğin Spiro Kostof un 1985'de yayınlanan A History of Architecture: Settings and Rituals / Bir Mimarlk Tarihi: Yerlessimler ve Ritüeller adlı eseri mimarlık tarihi yazımın derinden etkileyen yapıtlar için iyi bir örnektir. Kostof un çalışması mimarlık tarihinde alışlageldik kalıpların yıkılması için önemli bir kilometre taşıdır. Kostof tarihsel toplumların birbirlerinden yalıtılmıs bir şekilde ele alınmalarını reddederek tarihte Doğu - Batı arasındaki sürekliliklerin vurgulamış ${ }^{10}$ ve aynı zamanda da mimarlık tarihinin salt anıtsal yapılardan oluşan bir seçki olarak görülmesine karşı çıarak sivil mimari örneklerine ve toplumun "sıradan" kesimlerinin yaşam kalıplarına da önem vermiştir. Bu yaklaşımın günümüzde de etkisini arttırdığı gözlenmektedir ${ }^{11}$.

Küreselleşme ve kültürler-arası diyalogun önem kazandığı çağımızda sanat, tasarım, estetik ve mimari kültüre ilişkin tüm tarihi biri-

${ }^{9}$ Thomas Carter ve Elizabeth C. Cromley, Invitation to Vernacular Architecture, A Guide to the Study of Ordinary Buildings and Landscapes, The University of Tennessee Press, Knoxville 2005.

${ }^{10}$ Spiro Kostof, A History of Architecture: Settings and Rituals, Oxford University Press, New York 1985, s.453-510.

Kostofun eseri mimarlık tarihinde doğu - batı sürekliliklerini vurgulaması açısından çğır açmıştur. Örneğin 16. yüzyll mimarisinin anlatımında yer alan bir kitap bölümü "İstanbul ve Venedik" olarak adlandırılmıs ve uygarlıklar arasındaki tarihsel etkileşimler içeriğe de yansıtularak örnekler ile ortaya konmuştur.

"Francis D.K. Ching, Mark M. Jarzombek, Vikramaditya Prakash, A Global History of Architecture, John Wiley \& Sons, New Jersey 2007.

Küresel bir mimarlık tarihi yazımı iddiasını taşıyan en güncel çalışmalardan biri olan bu eser tarihi çeşitli kronolojik dilimlere ayırarak seçilen zaman aralığında dünyanın her köşesinde yer alan dikkate değer mimari eserleri incelemektedir. 
kim insanlığın ortak mirası olarak değer görmektedir. Bunun sonucu olarak çeşitli coğrafi bölgelerin sanat ve mimari tarih yazımlarında birbirlerinden yalıtılmıs olarak ele alınmaları geçmişte çok rastlanan bir durum olmasına rağmen artık günümüzde kabul görmemektedir. Neticede çağdaş mimarlık tarihinde sivil ve kırsal mimarinin önem kazandığını görüyoruz ${ }^{12}$. Son ylllarda ülkemizde de bu yöndeki bilimsel çalısmaların arttı̆ı gözlenmektedir ${ }^{13}$.

Bu bağlamda uygarlık kavramını yerleşik olmak ile denk gören düşünce kalıbının da yıkılması Türk mimarlık tarihi açısından önemlidir. Tarih ve felsefe gibi sosyal bilim dallarında da göscer toplumlann yerleşik toplumlar ile ilişkileri, göçer toplumların tarih yazımında maruz kaldıkları ihmal ve buna karşın göçer kültürlerdeki incelikler ve zenginlikler keşfedilmeye başlanmıştır ${ }^{14}$. Bu gelişme felsefe, antropoloji, sosyoloji ve mimarlık tarihi gibi sosyal bilimlerin pek çok disiplininde kendini göstermektedir. Örneğin göçer mekansal kurgulardaki ekolojik ve sürdürülebilir nitelikler keşfedilmiş ve bu alanlardaki bilimsel çalışmalar her geçen gün daha çok önem kazanmışur ${ }^{15}$.

Sözü edilen değişimlerin hepsi Orta Asya ve Anadolu Türk toplumlannda yerleşim kalıplanı ile kültürel ve mekânsal öğeleri hakkındaki araşırmaların önem kazanmasını sağlamıştur. Göçer ve yarı-göçer Türk topluluklanı mekândaki yüksek hareket kabiliyetleriyle doğa ile yakından ilişkili olmuşlar ve iklimsel döngüler uyarınca yer değiştirerek kültür doğa uyumunu kurmuşlardır. Bu veriler ışığında Türk konut mimarisindeki tarihsel gelişimin çok boyutluluğu ortaya çıkmıştır. Mekândaki hareketliliklerinden dolayı değişik kültürler ve yeni coğrafyalar ile yakın etkileşim halinde gelişen Türklerin mimarisini tekil ve doğrusal bir gelişim kalıbına oturtarak etkileşim halinde olduklan kültürlerin ve coğrafyaların katkılarından bağımsız olarak düşünmek mümkün değildir.

${ }^{12}$ Spiro Kostof, "Junctions of Town and Country," Dwellings, Settlements and Tradition: CrossCultural Perspectives, University Press of America, Lanham - New York - London 1989.

Uygarlık gelişiminin sadece kentlerde oluştuğunu iddia eden önyarglar kırılarak kentsel ve kırsal mekânlanın bir bütünün parçası olduklan anlaşılmıştır. İnsanoğlu kentleri kurarken çevresindeki kırsal alanları da derinden etkilediği gibi kentlerin sürdürülebilirliği açısından bu alanlara daima bağımlı olmuş ve buralarda tarihsel izler burakmıştur.

${ }^{13}$ Kemal Aran, Bannaktan Ote: Anadolu Kir Yaptlan, Tepe Mimarlık Kültürü Merkezi, Ankara 2000.

${ }^{14}$ Gilles Deleuze ve Félix Guattari, A Thousand Plateaus: Capitalism and Schizophrenia, çev. Brian Massumi, University of Minnesota Press, Minneapolis - London 1987.

Is İbrahim Bakur, Bah Toroslarda Göşerlerin Yerleşme ve Mekân Sonunlannen Cözzümü Uzzerine Bir Deneme (Yayınlanmamış Doktora Tezi) Selçuk Üniversitesi, Konya 1995. 
Bu makalede Türklerin konut mimarisindeki tarihsel süreklilikleri sözü edilen çok boyutluluk içerisinde değerlendirebilmek amacıyla mimarinin işlevsel ve fiziksel boyutlarına odaklanan bir kavramsal çerçeve önerilmekte ve bu öneri örnekler ile desteklenmektedir.

\section{TÜRKLERDE GELENEKSEL MEKÂN KURGUSU: ORTA ASYA VE ANADOLU}

\subsection{Türklerde Geleneksel Mekân Kurgusu: Orta Asya}

Orta Asya kaynaklı göşer Türk mimarisinde mekânsal algıdan söz edildiğinde insan-çevre bütüncüllüğü öne çıkar. İnsanın barınak haline getirdiği ve bu amaç için çevresindeki doğal malzemelere şekil verdiği yaşama mekânı salt kapalı mimari birimler ile sınırlı olmayıp tüm doğal çevreye yayılmaktadır. İnsan-çevre ilişkisinde kendini yeryüzünün ayrılmaz bir parçası olarak gören çevre duyarlı yaklaşım göçebe toplumların ortak özelliğidir ${ }^{16}$.

Mekân tarifi mimarlığın özünü oluşturur ve sınırsız doğanın içerisinden çeşitli hacimlerin insani eylemler ile eşleştirilerek tanımlanmasını içerir. Tanımsız uzayın kültürel ve çevresel verilerle örülerek "yer" halini alması mimarinin temel işlevidir. "Yer" (place) çevresel karakterin yoğunlaşma noktasıdır ${ }^{17}$. Bu yoğunlaşma noktasında temel çevresel veriler olan yapı malzemeleri ve kültüre bağlı olarak gelişen işlev şeması örtüşür. "Yer" üretimi bu örtüşmeyle oluşur. Mimarlı̆ın esas hedefi ve çalşma konusu olan mekân ise "yer" üretiminin sonucudur. Mekân kurgusu doğal malzemelerin işlevsel ihtiyaçlar doğrultusunda şekillendirilmesiyle oluşur.

"Yer" tanımına geri dönülürse mekânsal kurgunun iki boyutundan söz edilebilir: fiziksel kurgu ve işlevsel kurgu. Uzayda soyut ölçülerle ifade edilebilen hacim ve yapı malzemeleri kültüre göre şekillenen insan eylemleri ile eşleşerek mekânsallaşır. Mekân tarifi, yer düzlemini insanoğlunun barınma eylemi uyarınca sınırlandıran en yalın müdahale ile başlar ve çeşitli kapalılık düzeyleri ile devam eder. Mimaride benzer insan-çevre ilişkileri tüm geleneksel toplumlar için geçerli olmakla birlikte mekânsal kurguları, çevreye uyum sağlamak kaydı ile Türk toplumlarına özgü bir biçimde oluşmuşlardır.

${ }^{16}$ Jale Erzen, Çare Estetiğ. ODTÜ Yayıncllk, Ankara 2006, s. 127-128.

${ }^{17}$ Christian Norberg-Schulz, The Concept of Dwelling; on the Way to Figurative Architecture, Rizzoli International Publications, New York 1985. 
Orta Asya Türklerinin temel yaşam birimi olarak kabul edilen "yurt" ele alındığında mimari form üretiminin çevresel ve kültürel referansları anlaşlabilir. Anadolu'da "topak ev" olarak adlandırılan yurt geometrik form olarak silindir bir kaidenin üstüne oturtulan eşit çaph yarım küreden (kubbe) oluşur. Yurt üç boyutta hasır örgü mantı̆̆ ile teşekkül ettiği ve keçeyle örtüldüğü için hafiftir. Katlanabilir olan hasır strüktür sayesinde yurt kolayca taşınabilir. Yurdun cepheleri de dolu boş, açık - kapalı ilişkileri açısından esnektir. Keçe örtüler ışık ve hava almak amacıyla yukarı katlanabilir ${ }^{18}$. Buraya kadar anlatılanlar yurdun fiziksel kurgusudur (Şekil 1).

İşlevsel kurgu açısından incelendiğinde yurdun net bir şemaya sahip olduğu görülür. İşlevsel kurgu göçer kültür ile şekillenmektedir. Pişirme yeri (ocak) dairesel planın merkezinde yer alırken çeperlerin oturma, yatma, yeme vb. çeşitli işlevler ile yüklendiği ve bu işlevleri karşılayan elemanların taşınmaya hazır biçimde oldukları görülür (Şekil 1). Tarihsel kaynaklarda Türklerin ana yurdu olarak ifade edilen Orta Asya'daki göçebe yerleşimlerin yilın değişik zamanlarında ve özellikle de yazlık ve kışlık zaman dilimlerinde farklı coğrafi bölgelerde kümelenmesi mekânın dinamik yapısının artmasına ve mekânda esneklik ve akışkanlığın sağlanmasına katkıda bulunmuştur.

Yurt bozkırda seçilen bir noktada kurulduğu andan itibaren çeperlerini aşan bir ölçekte mekân tarifine sebebiyet verir. Su kaynakları dışında dikkate değer referans noktası olmayan bozkırda mekân tanımının başlama noktasını yurt oluşturur. (Şekil 1) "Çevrenin mekânsallaşması" Orta Asya bozkırında önemli bir yere sahiptir. Yurtlar kümesi bozkırdaki konumları itibarı ile düşünüldüklerinde "yer" üretme potansiyelleri açısından değer kazanırlar (Şekil 2).

Eskiden olduğu gibi bugün de, Asya'nın iç bölgelerinin uçsuz bucaksız ağaçsız düzlüklerinde insanların yaşamlarını yönlendirebilecekleri tek yer yurttur. Burası insanın kavrayamadı̆̆ı, sonsuz mekânın mikrokozmik bir yaşantuya dönüştüğü yerdir. Vadide, ormanda ya da deniz kıyısında oturan biri yaşamının değişmez değerlerini bunlara dayandırabilir; ona ağaç gölgeleri, suyun yansımaları, koruyucu yamaçlar yön verir. Bozkırlarda yaşayanlar ise bunların hiçbirine sahip değildir. Her türlü referans öğesi kişiler tarafindan evlerin-

${ }^{18}$ Anton Bammer, “Çadır ile Anadolu Evi İlişkileri," Tarihten Günümüze Anadolu'da Konut ve Yerleşme - T.C. Başbakanlık TOKI II. B.M. Insan Yerlesimleri - Habitat 1996 Konferanst Bildiniler ve Sergi Kitabr (1996), s. 236. 
de yaratılmalıdır. Onların elinde astronomik eksenler, güneşin doğuşu ve batışı, bütün olarak gökkubbe ve merkez olarak da yurt vardır. Böylece çadır evrenin 'karşı' yansıması olmaktadır; çatıdaki delik gökyüzünün gözü yani güneş, çatı da kubbeli, kapalı gökyüzünü temsil etmektedir. Diyalektik bir çevrim söz konusudur; güneş ışı deliğinin, sınırsız gökyüzü ise sınırlı kubbenin karşılı̆ıdır ${ }^{19}$.

Dolayısıyla göçebe Türklerde mekân algısı, doğal malzeme çatkılarından oluşturularak özgün bir "yer" halini alan çadırların kendi fiziksel kurgularından ibaret değildir. Çadırların kapalı hacimlerinin ötesinde çevreye yayılan bir mimari anlayıştan, fiziksel ve işlevsel boyutlarıyla topyekûn bir mekânsal kurgudan söz edilebilir.

Bununla beraber Orta Asya Türk toplumlarında sadece göçebe yerleşim kalıplarının hâkim olduğu ve Orta Asya Türklerinin Anadolu’ya göçtükten sonra yerleşik yaşamı benimsedikleri düşüncesi bilimsel değildir. Arkeolojik kazılar ışı̆ında şekillenen güncel bilgi ile Orta Asya'da yerleşik kültür oluşturmuş Türk toplumlarının inşa ettikleri barınma birimleri de gün ışı̆ıına çıkmıştur. Kazakistan-Çu Vadisi, Türkmenistan, Aral Gölü çevresi ile Sırderya Boyları'nda ortaya çıkan ve Ortaçağa ait olduğu kabul edilen konutlar Türklerin Anadolu'da oluşturdukları yapı çevreleriyle mekânsal süreklilikler göstermektedirler ${ }^{20}$ (Şekil 3).

Aynı zamanda Türklerin Anadolu'daki konut gelenekleri dikkatle incelendiğinde "yerleşik" ve "göçebe" kategorilerinin de birbirlerinden net bir biçimde ayrılamadığını gözlemliyoruz. Bir başka deyişle, Bammer'in da ifade ettiği gibi, "yerleşik yaşamakla sürekli konutlarda yaşamanın, göçebe yaşamla da taşınabilir barınakların ilişkili olduğu fikri her zaman doğru değildir."21 Güneybatı Anadolu'daki Toros Dağları üzerinde yer alan kırsal yerleşmelerde çiftçilik ile geçinen ve "yerleşik" olarak görülen köy toplumlarının yazın ve kışın farklı konutlarda yaşadıkları bilinmektedir. Bu tip “yarı-göçebelik” Anadolu'da önemlidir²2.

Bu verilerden hareketle Türklerin Orta Asya'da "göçebe" yaşadıkları Anadolu'ya geçişleriyle "yerleşik" hayata geçtiklerine dair düşüncenin bilimselliği sorgulanmaya açılmıştır. Öncelikle "göçebe / göçer" sıfa-

${ }^{19}$ Bammer, a.g.m., s. 236-237.

${ }^{20}$ Bekir Deniz, "Orta Asya'daki Eski Türk Evleri," Akdeniz Universitesi Güzel Sanatlar Fakültesi Akdeniz-Sanat Dergisi I, Antalya 2008, s. 17.

Ayrıca Mustafa Cezar, Anadolu Oncesi Türklerde Şehir ve Mimarlık, Türkiye İş Bankası Yayınları, İstanbul 1977.

${ }^{21}$ Bammer, a.g.m., s. 234.

${ }^{22}$ Bammer, a.g.m., s. 239. 
tının tam olarak neyi karşıladığı açıklı̆g kavuşturulmalıdır ${ }^{23}$. Türklerde göçerlik amaçsız veya rastgele mekân değişimleri değildir ${ }^{24}$. Göçer Türk toplumlarında mekânda hareket tanımlı güzergahlarda ve belirli amaçlara yönelik olarak gerçekleşir (Şekil 4). Orta Asya'da olduğu gibi Anadolu'da da belirli göç güzergâhları vardır. Amaç mevsimsel sıcaklık farklarından korunmak ve tüm yll boyunca hayvanlara yiyecek bulabilmektir. Hayvanlar temel geçim ve besin kaynağı oldukları gibi mimarinin de malzeme kaynağıdır. Orta Asya ve Anadolu'daki "topak ev" yapllarında hasır örgü üzerine kaplanan keçe ile istenen ölçüde kapalılık sağlanmıştır.

Güncel bulguları dikkate alan daha geniş bir bakış açısından hareket ile Türk mimarisinde tarihsel sürekliliklerin araştırılmasında "göçebe" ve "yerleşik" kategorilerinin anlamsızlaştığı görülmektedir. Düz mantık ile "Orta Asya'da göçebe" ve "Anadolu'da yerleşik" oldukları varsayllan Türkler Orta Asya'da önemli yerleşim merkezleri kurmuşlar, Anadolu'da ise ihtiyaca göre göçer ve yarı-göçer yaşam kalıplarını devam ettirmişlerdir. Bu bağlamda tartışılması gereken konu "göçer yerleşik" karşıtlığından çok Türklerin mekânsal düzenlemelerini şekillendiren soyut ilkeler, bu ilkelerin işlevsel boyutları, tarihsel devamllıkları ve çevresel değişimlere göre vücut bulma biçimleridir.

\subsection{Türklerde Geleneksel Mekân Kurgusu: Anadolu}

Türklerin Orta Asya - Anadolu geçişinde mekânsal kurgularının ne tür bir değişim geçirdikleri konusunda ortaya atılmış düşünceler genelde göçebe çadır ile Anadolu evi arasında doğrudan bir evrim önerisinde bulunmuşlardır ${ }^{25}$. (Şekil-5) Ana hatları bu yazının giriş bölümünde verilen çağdaş mimarlık tarihi yazımı açısından bu görüş zayıf gözük-

${ }^{23}$ Tanyeli, a.g.m., s. 417.

Orta Asya'daki Türk ve Moğol boylarının yüzyllar boyunca sürdürdükleri "bitimsiz ve uzun mesafeli" devingenlik ile coğrafya terminolojisinde "transhümans" adı verilen hayvanalığa bağh mevsimsel yer değiştirmeler arasında fark vardır. Transhümans toplulukların güzergahları ve takvimleri tanımlıdır ve her sene aynı şekilde devam eder. Tanyeli farkı açklarken Orta Asya göçebesinin yer değiştirmelerinin siyasal sonuçlan olduğunu fakat Anadolu'daki "transhümansın" yerel ölçekle sınırı bir yaşam biçimi olarak kaldığını söyler.

${ }^{24}$ İbrahim Bakır, "Toroslarda Göçebe Mimarisi". T.C. Kültür Bakanlı̆̆ Halk Külttürïnü Araştıma Dairesi Yaynlan: 148 - Türk Halk Mimarisi Sempozyumu Bildiriler Kitabı, 1990, s. 17-30.

${ }^{25}$ Önder Küçükerman, Kendi Mekanmen Arayz̧̧ If̧inde Türk Evi. Turing Kurumu, İstanbul 1996, s. 33-35.

Bammer, a.g.m., s. 237. 
mektedir ${ }^{26}$. Değişik coğrafyalara yayıldıkça değişmeden kendini muhafaza eden keskin kalıplardan söz etmek mümkün değildir. Mimarlık tarih boyunca yaşam ve kültürün somut ifade biçimi olduğuna göre kültürel yapının karmaşıklğı ve mimari üretim üzerindeki çok çeşitli faktörler iddia edilen doğrusal gelişim hakkında şüphelere yol açmaktadır.

Türkler'in Orta Asya'dan Anadolu'ya önemli mekânsal ilkeler taşıdıkları açık olmakla birlikte ${ }^{27}$ sürecin uzunluğuna ve geçişin gerçekleştiği coğrafyanın genişliğine nazaran eldeki somut mimari bulgular genellemelere varmak için yetersizdir ${ }^{28}$. Şimdiye kadar önerilen genellemeler sözü edilen nedenlerle sürekli olarak sorgulanmıştır ${ }^{29}$. Bu bağlamda süreci basitleştirme riskinden bahseden Tanyeli ${ }^{30}$, Anadolu konutunun tarihte karmaşı bir değişim ve oluşum sürecinden geçtiğini hatırlatmaktadır. Çadır - Anadolu evi arasında doğrudan bağ kuran görüşlerde evin ana bileşeninin "oda" olduğu ve "oda" ile Orta Asya kökenli olan ve çadırı ifade eden "otağ" kelimeleri arasında etimolojik bağ bulunduğu dile getirilse de Tanyeli'ye göre "çadırdan odaya giden yol araşturmacılar tarafindan oldukça kestirme ve dolaysız düşünülmüştür." ${ }^{31}$ Tanyeli öne sürülen süreklilikleri kabul etmekle beraber "uzak geçmişin zor sorgulanabilen izlerinin doğrudan mekana tercüme edilmesi” işlemine karşı çıkmaktadır. Ayrıca topak ev ile oda arasında kurulan biçimsel bağda da (Şekil 5) zayıflıklar bulunduğu, örneğin topak evde girişin simetri ekseni ile çakıştı̆ı odada ise eksenellik olmadığı, odanın dış mekana dönük yapılanmasına karşın topak evin içe dönük olduğu düşünülmektedir ${ }^{32}$.

${ }^{26}$ Ayda Arel, Osmanl Konut Geleneğinden Tarihsel Sonunlar, Ege Üniversitesi Güzel Sanatlar Fakültesi Yayıları No:11, İzmir 1982.

${ }^{27}$ Tanyeli, a.g.m., s. 415

Anadolu'da özellikle 11. yüzyldan itibaren kendini gösteren demografik değişimin aktörlerini Tanyeli "yerleşikler ve göçerler" olarak tanımlamakta ve göçerlerin taşıdığı barınma pratikleri konusunda daha sağlam yargilara varılabileceğini belirtmektedir. Tanyeli'ye göre "kara çadır", "topak ev", ve "alaçık" olarak adlandırılan "göçer strüktürlerin" özellikleri zaman ve mekân fárklılaşmasına karşın az değişmiştir ve bu durum "Orta Asya-Anadolu bağlantısı konusunda tereddütsüz konuşabilmeyi sağlar."

${ }^{28}$ Tanyeli, a.g.m., s. 405 - 410 .

Veri yetersizliği sadece Türklerin konut mimarisi ile ilgili olmayı genel bir sorundur. Konut tarihinin çeşitli basamaklannda "kara noktalar" bulunmaktadır. O̊rneğin Anadolu'da "Antik Çă̆ ve Geç Antik Çağlarda oldukça geniş bir yapısal repertuar ile temsil edilen konut mimarisi Bizans'ta aydınlatıc örneklerden büyük oranda yoksundur."

${ }^{29}$ Doğan Kuban, Anadolu-Türk Mimarisinin Kaynak ve Sorunlan, ITÜ Mimarlık Fakültesi Yatunlan, İstanbul 1965.

${ }^{30}$ Tanyeli, a.g.m., s. 406.

31 Tanyeli, a.g.m., s. $425-427$.

${ }^{32}$ Tanyeli, a.g.m., s. $425-426$. 
Bu veri eksiklikleri dikkate alındığında Önder Küçükerman ${ }^{33}$ tarafindan öne sürülen sürekliliklerin soyut mekânsal ilkeler düzeyindeki süreklilikler olarak kabul edilmesi daha uygundur. Orta Asya-Anadolu sürekliliğini tesis eden ilkeleri sağlıklı bir şekilde değerlendirebilmek için asırları kapsayan karmaşık bir süreci basitleştirmekten kaçınmak, bunun yerine daha çok zaman üstü mekânsal ilkelerin şematik düzeyde sürekliliklerine odaklanmak daha doğrudur. Bu arada Türklerin Anadolu'ya giden yolda ve Anadolu'da diğer mimari kültürlerden ne derecelerde etkilendikleri konusunu kısaca değerlendirmek gerekir.

Orta Asya'dan Anadolu'ya geçiş ile birlikte coğrafi ve iklimsel özelliklerde köklü değişimler olduğu ve aynı zamanda Anadolu'nun tarihsel derinliği içerisinde çevresel koşullar ile bütünleşmiş çeşitli yapı gelenekleri ${ }^{34}$ ile karşılaşıldığı bilinmektedir. Özellikle XI. ve XII. yüzyıllardan itibaren Türk topluluklarının Anadolu'daki nüfus artı̧ı ile bu coğrafyaya has çevresel özellikler ve yapı gelenekleriyle harmanlanmıs sivil konut mimarisi oluşmuştur ${ }^{35}$. Kuban'a göre bu mimari özellikler Osmanlı Devleti ile birlikte Balkanlar ve Orta Avrupa'ya kadar yayılmıştır. Yerleşik mekândaki gelişmelerin yanı sıra Anadolu'nun iç ve kıyı bölgelerinde göçer ve yarı-göçer Türk topluluklarının coğrafi şartlara adapte olarak kültürlerini günümüze kadar ulaştırdıkları gözlenmektedir ${ }^{36}$.

${ }^{33}$ Küçükerman, a.g.e.

${ }^{34}$ Rudolf Naumann. Eski Anadolu Mimarlğı, Türk Tarih Kurumu, Ankara 1991.

35 Tanyeli, a.g.m., s. 415 - 416.

Tanyeli bu oluşumun kent ve kırda farklı biçimde gerçekleştiğini düşünmektedir. Kentlerde kırsal kesime nazaran çok daha tanımlı gelenekler bulunmaktaydı. Bu sebeple kentlerde "Türk alışkanlıklarıyla yerleşiklik mimarisinin" sentez yapıldığı düşünülmektedir. Tanyeli'ye göre S.H. Eldem'den itibaren kurulan "Türk Evi" tipolojisinin daha çok kasaba ve kentlerdeki örneklere odaklandığını ve kırsal kesimdeki konut örnekleriyle ilgili çalışmaların sınırh sayıda olduğu görülmektedir. Tanyeli tarihsel gerekçelere dayanarak Antik Anadolu mimari gelenekleri ile Türklerin Orta Asya'dan taşıdıkları mekânsal kurgular arasında kurulan sentezin daha çok kentsel merkezlerde kurulmuş olabileceğini, kırsal kesimdeki konut mimarisinin yerleşikliğe geçen Türkmenlerin antik yapı geleneklerinden çok çevresel veriler ile bütünleşmesi sonucunda gerçekleştiğini düşünmektedir. Ne var ki 11. Yüzylda kentsel - kırsal alanlarda oluşan konut yapıları arasında sağlıkı bir karşılaştırma yapabilecek düzeyde veriler elimizde bulunmamaktadir.

${ }^{36}$ Bakır, "Toroslarda Göçebe Mimarisi", s. 18.

Bakır, Osmanh İmparatorluğu gerileme döneminden itibaren çıkarılan iskân kanunlanna rağmen göçebe hayvançlı̆ın yüksek ekonomik değere sahip olması vb. nedenlerle göçer yaşam kalıplarının devam ettiğini fakat 1950'lerden başlayarak "tarım topraklarının meralar aleyhine artması, orman kanunu hükümlerinin sertleştirilmesi” nedenleriyle göçebe yaşamın güçleştiğini ifade eder. Neticede birçok Yörük aşireti kışlak olarak kullandıklan bölgelere yerleşerek ilkbahardan sonbahara kadar az sayıda hayvanla yaylaya göçmeye başlamıslardır. Tarum teknolojisindeki gelişmeler ve hayvancilhk gelirlerinin düşmesiyle birlikte daha çok toprağa bağlanan Yörüklerin yaz aylannda ancak bir - iki ay yaylaya çikmalan söz konusudur. 
Anadolu çevresindeki coğrafyalar ile kültürel etkileşimleri değerlendiren Doğan Kuban Anadolu'nun coğrafi özellikleriyle ilişkili bir “Türk Evi Tipi” ortaya koyar ${ }^{37}$. Bu tipoloji Anadolu'yu çevreleyen coğrafyalar ile etkileşerek gelişmiştir. Örneğin Güneydoğu Anadolu Mezopotamya ve Suriye ile Doğu Karadeniz ise Kafkaslar ve Azerbaycan ile bağlantılı olarak gelişmiştir. Hiçbir yöresel geleneğin saf olmadığına işaret eden bu veriler yazının giriş bölümünde bahsedilen coğrafyalar aras1 etkileşimin Türk konut mimarisinin doğru bir tarihsel perspektife oturtulabilmesi için ne kadar önemli olduğunu gösterir.

Anadolu'daki yerleşik yapı gelenekleri ile Orta Anadolu'daki Türk konut mimarisinin ilişkisi düşünüldüğünde ise Orta Anadolu'daki kerpiç geleneğinin "insan açısından bakıldığında neredeyse ebedi” olduğu vurgulanmaktadır. ${ }^{38}$ Dolayısıyla Anadolu'daki Türk konutlarından söz edildiğinde bu yapıların uzun bir sentezin ürünü olduğu ve malzeme kurgulan itibarı ile Anadolu'da Türk nüfusunun tarihsel olarak yoğunlaştuğı Selçuklu Dönemi'nden çok önce günümüzden en az 10 binyll öncesinde temellendiği göz önüne alınmalıdır ${ }^{39}$.

Geleneksel Anadolu-Türk konutlarındaki mekânsal algı açısından konuya bakıldığında sözünü ettiğimiz yapı grubunun terminolojisinin kurulması ve tek bir tip altında toplanmasının zor olduğu görülmektedir. Anadolu'nun değişik bölgelerinde iklim ve coğrafyaya özgü mimari geleneklerin oluştuğu ortadadır. Fakat mekânsal işlev şeması ve açk - yarı açık - kapalı mekân geçirgenlikleri açısından incelendiğinde hem Anadolu'daki konutlar, hem de Orta Asya göçebe ve yerleşik mimarisine dair bulgular arasında paralellikler gözlenmektedir (Şekil-1). Mekânda işlevsel esneklik, çok amaçlılık, dönüştürülebilirlik, hafiflik, yalınlık değişik coğrafyalara yayılan Türk toplumlarında konut mekânının zaman üstü ilkeleri halini almıştır. Öyleyse işlevsel şema açısından ortak bir dile sahip olan konutların Anadolu'nun değişik bölgelerinde farklı malzeme kurguları ve teknikleriyle ortaya çıkarak günümüze ulaştıkları söylenebilir. Daha detaylı bir inceleme ile Osmanlı coğrafyasindaki Anadolu ve Balkanlar'a tekabül eden ortak mimari dilin işlev şemasının soyut dilinin ötesinde yaşam birimlerinin iç mekân organizasyonlan ve mimari öğeleri arasında oluştuğu da gözlenmektedir.

${ }^{37}$ Doğan Kuban, The Turkish Hayat House, M.T.R., İstanbul 1995, s. 3-4.

${ }^{38}$ Kuban, The Turkish Hayat House, s.1.

${ }^{39}$ Sey, a.g.m. 
Mimarinin temel barınma ihtiyaçlarını karşılama, çevreyle bütünleşme biçimleri ve yapı teknikleri açısından evrensel ilkeler ile şekillenen mekânların karşıladığı işlevsel özellikler kültürlere göre şekillenir. Öyleyse Anadolu geleneksel konut mimarisinde de mekânsal kurguyu araştırırken birbiriyle bütünleşik iki düzeyden söz etmek mümkündür:

i. İşlevsel Kurgu:

Orta Asya göçebe yaşam kalıplarına dair işlevsel esneklik, çok amaçlılık vb. zaman üstü ilkelerce şekillendirildiği düşünülen ve Anadolu'nun değişik bölgelerindeki ortak iç mekân dili ile doğrulanan şematik ve soyut ilkeleri ifade eder. Örneğin Kuban'ın "Hayat Evi” olarak nitelendirdiği Türk konut tipolojisi sözü edilen işlevsel kurguyu barındırmaktadır ${ }^{40}$. Özellikle 15. yüzyıldan itibaren Osmanlı idaresinin sağladığı siyasi istikrar ortamında, "yerleşik yaşama yeni geçmiş göçer topluluklar" tarafindan Anadolu'nun eski kentlerinde ve dolaylarında "yarı kırsal ve yalın" bir ifade ile üretilen konutlar Türklere özgü bir işlevsel kurgunun Anadolu'nun antik yapısal gelenekleriyle oluşturduğu sentezi temsil etmektedir.

\section{ii. Fiziksel Kurgu:}

İklim, yerel malzemeler vb. çevresel koşullar ışığında yöreye özgü olarak sentezlenen ve ayn zamanda Anadolu'nun antik yapı gelenekleri ile süreklilikleri tespit edilebilen somut mimari yapıyı ifade eder (Şekil 6). Kuban'ın vurguladığı gibi ${ }^{41}$ Anadolu geleneksel konutlarında görülen yapı tekniklerinin çoğu günümüzden yaklaşı M.Ö. 5000'lerde gelişmiş durumdadır. Tanımlanabilir konut kültürlerinin oluşumu teknik zorunluluklardan çok burada "işlevsel kurgu" kapsamında ele alınan sosyokültürel yapılar ile ilişkilidir. Fiziksel kurgudaki sürekliliklerin araştırılması özellikle Anadolu'daki konut kültürünün tarihsel derinliğini ve işlevsel değişimler ile beraber üretilen sentezleri ortaya çıkarmak bakımından önem taşır.

\section{TÜRK KONUT MIMMARİSI: KARŞILAŞTIRMALI TARİHSEL}

\section{1. İşlevsel Kurgu Açısından İnceleme}

Türk konut mimarisinde Orta Asya - Anadolu sürekliliği konusunda şimdiye kadar ortaya konmuş düşünceler arasında en çok bilinenler-

\footnotetext{
${ }^{40}$ Kuban, The Turkish Hayat House.

${ }^{41}$ Kuban, The Turkish Hayat House, s. 4.
} 
den biri Küçükerman'ın oda ile çadır arasında kurduğu doğrudan ilişkidir ${ }^{42}$. Buna göre "Türk evindeki odaların en önemli özellikleri kendi başlarına, yapı içinde belirli eylemleri karşılayan birimler olmalarıdır." Bu özellik ile "göçebelik dönemindeki çadırlar gibi, her oda: oturma, yemek yeme, çalışma, yatma gibi eylemlerin gerçekleştiği bir ortamdır." $\mathrm{Bu}$ düşünceye göre yerleşik düzendeki Türk evinin temel birimi olan oda ile göçebe düzenin temel barınma birimi olan çadır arasındaki süreklilikler şöyle sıralanmıştır (Şekil-5):

i. "Çok amaçh orta alan"

ii. "Oturma için biçimlenen çevresel alan"

iii. "Kapalı kullanma alanları: sekiler, sandıklar, yükler"

iv. "Isıtma (çadırda ortada bulunan ocak odada yana kaymıştır)"

v. Diğer mekânsal birimler ile ortak bir açık alan üzerinden bağlanti ${ }^{43}$

Önceki bölümlerde değinilen eleştiriler ışığında ${ }^{44}$ bu ilkelerin mekana "doğrudan tercümesinden" kaçınılması ve bunların soyut ve işlevsel düzeylerde ele alınması daha doğru gözükmektedir. İşlevsel kurgunun zamanüstü ve soyut yapısını daha iyi anlamak için Christopher Alexander'in "kalıp" (pattern) ve "kalıp dili" (pattern language) kavramlarına başvurulabilir ${ }^{45}$. Kalıplar, en sade tanımıyla geleneksel toplumlarda belirli işlevleri karşılayan işlevsel kurgular olarak görülebilir. "Kalıplar" dünyanın değişik yerlerindeki geleneksel mimarlık örneklerinden ilham alınarak ortaya konmuştur. Bir "kalıp" üç öğenin çakışmasından oluşur: belirli bir çevresel bağlam, bu bağlamın ortaya çıkardığı bir problemler kümesi ve bu bağlamsal problemleri çözen belirli bir mekânsal kurgu ${ }^{46}$. Bir kalıbın bu soyut tanımı tüm kültürler için geçerlidir fakat yukarıda verilen kural uyarınca şekillenişi kültüre özgüdür ${ }^{47}$.

Kalıplar, üç boyutta ve değişik ölçeklerde sayısız şekillerde bir araya gelerek belirli bir kültüre özgü mimari dili oluştururlar. Dil benzetmesiyle mimarinin kültürel devamlılıktaki rolü açı bir şekilde ifade edilir.

${ }^{42}$ Küçükerman, a.g.e., s. 68.

${ }^{43}$ Küçükerman, a.g.e., s. 68.

${ }^{4}$ Kuban, The Turkish Hayat House; Tanyeli, a.g.m.

${ }^{45}$ Christopher Alexander vd., A Pattem Language: Touns, Buildings, Construction Oxford University Press, New York 1977.

${ }^{46}$ Alexander, a.g.e., s. 247-253.

${ }^{47}$ Alexander, a.g.e., s. 463. 
Dilde olduğu gibi, mimari geleneğin bilgisi kolektif bir şekilde inşa edilir, paylaşılır, yeniden yorumlanır ve çevresel şartlara adapte edilerek sonraki nesillere aktarılır. Alexander'in çalışmaları Batı dışı kültürlerin geleneksel mimarisinden ve özellikle de Türk evinin mekânsal kurgusundan büyük ölçüde etkilenmiştir. Küçükerman'ın önerileri Alexander'ın tarif ettiği "kalıp" tanımı çerçevesinden değerlendirildiğinde Anadolu geleneksel konut mimarisindeki mekân kurguyu zengin tarihsel arka planı açısından daha sağlıklı değerlendirmek mümkün olacaktır.

Küçükerman tarafindan Türk evi odası ve topak ev arasında kurulan benzerlikte öne sürülen ortak noktalardan olan "çok amaçlı orta alan" ve "oturma için biçimlenen çevresel alan" Alexander'in öne sürdüğü "kalıp" tanımına uyum sağlamaktadır. Bu kalıplar Batı Anadolu'da Yörüklerin kullandığı kara çadırlarda da görülmektedir (Şekil 7). Yapısal olarak kubbe şekilli ve hasır örgülü topak evden farklı bir biçimde kurulan kara çadır, düşey yönde direkler ve yatay yönde gergi ipleri ile desteklenerek bir asma-germe strüktürü oluşturan keçi kılı hammaddeli dokuma ile kurulur (Şekil 8). Biçimsel ve yapısal farklılıklar çevresel şartlara adaptasyon sebebiyle ortaya çıkmıs olmakla birlikte işlevsel kurgu açısından incelendiğinde benzer mekânsal kalıplar gözlenebilir. Kara çadırda iç mekân oturma, yatma, yemek yeme vb. işlevler ile yüklü "çok amaçlı" bir tek mekândır. İhtiyaca göre çadır direği hizasından çuval, kilim vb. elemanlar ile bölünebilen iç mekân esnek bir karaktere sahiptir (Şekil 7).

Topak ev, kara ģadır ve alą̧ık (Şekil 1, 2, 7, 8, 9) adı verilen geçici strüktürlerin Anadolu kır ve kentlerinde inşa edilen yerleşik düzen konutlan ile ortak özellikleri iç mekândaki organizasyona ek olarak iç - dış mekân arasındaki geçiş dizgesidir. Tipolojik yaklaşımlarda oda - çadır bağı genelde iç mekân organizasyonu açısından kurulduğundan bu konu yeterince işlenmemiştir. Oysa işlevsel kurgu iç, dış ve bunlar arasındaki geçişlerin hepsini kapsar. Bundan önce ifade edildiği gibi mimarinin özünü oluşturan "yer" tanımı ve "mekân" tarifi ${ }^{48}$ konutun fiziksel çeperlerinden taşarak çevreyi şekillendiren kültürel anlayışın çevreyi kucaklayan ölçeğinde değerlendirilmelidir.

Dolayısıyla daha önce de savunduğumuz gibi konut mekânının Orta Asya - Anadolu bağlantısında "göçer - yerleşik" kategorilerini aşan mekânsal - işlevsel devamlılıklar söz konusudur. Konuya bu açıdan ba- 
kıldığında alaçı adı verilen ve topak evin türevi olarak görülen çadır sisteminin ön uzantısı olarak ortaya çkan talvar dikkat çekicidir. Talvar ${ }^{49}$ (Şekil 9) Anadolu'nun farklı yörelerindeki yerleşik düzen konutlarında hayat, kösk veya ayazlık (Şekil 10) adı verilen açık ve yarı açık mekânlar ile işlevsel manada bir akrabalık sergiler.

Hatta evrimsel açıdan bakıldığında bazı araştırmacılar "taşınabilir barınaklardan sabit barınaklara geçişte" ilk mimari aşama olarak "dört taşıyıcı direk ve üstü yapraklarla örtülü düz bir damdan oluşan çevresi açık çardak"tan (Şekil 11) bahseder ${ }^{50}$. Bu yalın mekânsal organizasyonlar iç-dış sürekliliğini sağlayan "kalıp" olarak düşünüldüğünde geleneksel Türk konut mimarisini karakterize eden çevreyle yakın ilişki temasının zengin örneklerini verir ${ }^{51}$. Bammer "çadırın verdiği özgürlük ve bağımsızlık" duygusunun yerleşik düzende de devam ederek "havadar açik bir mekân olan köşk gibi öğelerde" vücut bulduğunu savunur ${ }^{52}$. Bir çok işlevi (oturma, uyuma, yeme, ibadet vb.) bünyesinde barındıran odaları birbirine bağlayan "sofa" mekânsal olarak "içerisi" ve "dışarısı" kavramlarını bir arada barındırmakta olup en dışarısıyla en içerisi arasında geçiş ve oturma işlevlerini karşılayan pek çok "ara bölge" üretilmiştir ${ }^{53}$ (Şekil 12).

Bu ara bölgeler Kuban'ın "Türk Hayat Evi” adını verdiği ve Osmanlı Döneminde 15. yüzyıldan itibaren Anadolu ve Balkanlarda kalıpları oturmuş bir tip olarak yerleşen "Türk Hayat Evinin" de temel işlevsel öğeleridir ${ }^{54}$. Hayat evinde katlar kesin işlevsel ayrımlar ile birbirinden ayrılmıştır. Zemin kat masif yığma yapıda olup sağırdır ve çevreye uymak amacyyla düzgün bir plana sahip değildir. Zemin katta ahır, depo, atölye, dükkân vb. servis mekânları bulunurken ikinci katta oturulur. İkinci kat zemin kat duvarlarından taşarak düzgün bir plana erişir ve ahşap kafeslerle şeffaflaşır. Bu şeffaflaşmayı sağlayan ahşap çerçeve sistemi dıs mekâna doğru yumuşak bir geçiş ve ara bölgeler ile çevreye yayllır.

49 Bakır, "Toroslarda Göçebe Mimarisi", s. 21.

${ }^{50}$ Bammer, a.g.m., s. 241.

51 İbrahim Bakır, "Teke Yöresi Konutlarında Yaşatulan Selçuklu Mimarlık Gelenekleri".

T.C. Antalya Valilĭgi Yayınlan IV. Selguklu Semineri Bildiriler Kïtabı, Antalya 1992, s. 11-24

${ }^{52}$ Bammer, a.g.m., s. 242.

${ }^{53}$ Bammer, a.g.m., s. 244.

${ }^{54}$ Kuban, The Turkish Hayat House, s. 4. 
Daha yakından incelendiğinde şeffaflık, çevreyle görsel ve fiziksel ilişkiler, geçişi sağlayan ara bölgeler bağlamında "yurt” yapısının iddia edildiği kadar içe dönük ve çevreden kopuk olmadığı görülebilir. Yurdun yapı sistemini oluşturan hasır örgünün şeffaflığı, çerçeve özelliği, yönlere ve ihtiyaca göre imkan verdiği iç - dış ilişkileri yerleşik düzendeki hayat evinin çerçeve sistemiyle dışa yayılmasında olduğu gibi doğa - kültür ilişkisini kurar.

Hayat evindeki odalar avlu ve teraslar ile çevrili ve yarı açık hayat etrafinda kümelenir. Hayat ve uzantıları (Şekil 10, 12) Türk konut mimarisindeki işlevsel kurgu süreklilikleri açısından yeterince incelenmemiş bir alandır. Orta Asya - Anadolu Türk konut mimarileri arasındaki süreklilik genelde çadır - oda arasındaki iç mekâna ilişkin işlev şeması benzerlikleri açısından ele alınmıştır. Oysa göçer, yarı-göçer ve yerleşik Türk toplumlarının mekânsal organizasyonlanı incelendiğinde Türk hayat evindeki "oda" birimini aşan ve çevreyle ilişkileri kuran işlevsel benzerlikler söz konusudur.

\subsection{Fiziksel Kurgu Açısından İnceleme}

İnsanlığın evrensel kültür mirasının somut öğesi olan mimarlık fiziksel kurgu olarak evrensel fakat işlevsel olarak kültüre özgü karakter taşır. Anadolu ve Orta Asya'daki geleneksel konut mimarisi incelendiğinde, Doğan Kuban'in deyimiyle "insanlık tarihi kadar eski" ${ }^{55}$ yapı malzeme ve sistemleriyle karşı karşıya kalıyoruz. Anadolu'da Çayönü'nde (Diyarbakır) tespit edilen erken Neolitik döneme ait yuvarlak konutlar (Şekil 13), dörtgen konut biçimine geçiş olarak görülen örnekler (Şekil 14), ve dörtgen konutlar (Şekil 15) yapı malzeme ve sistemlerinin zaman üstü ilkelerini ortaya koyar.

Buna karşın dünyanın dört bir tarafinda çevre verilerinin uygunluğuna göre ahşap, kerpiç ve taş gibi geleneksel yapı malzemelerinden ve benzer yapısal sistemlerden faydalanılarak vücut bulan geleneksel konutlar (Şekil 6, 15), fiziksel kurgularındaki benzerliklerin aksine, işlevsel olarak barındırdıkları kültürlerin ihtiyaçlarını karşılayacak biçimlerde farklılaşmıslardır. Bu tespit pek çok kültürü barındırmış olan Anadolu'daki tarihsel örnekler ile de çarpıcı bir şekilde doğrulanmaktadır.

\footnotetext{
${ }^{55}$ Kuban, The Turkish Hayat House.
} 
Türkiye'de ilk tarihöncesi kazıların başladığı dönemden bu yana çoğu araşturmacı tarihöncesi konut mimarlığının bu topraklarda neredeyse hala capcanlı yaşadığı yanılsamasına kapılmışır. Kerpiç duvarlar, düz toprak damlar ve neredeyse doğal zeminle bütünleşen bir mimari görüntü, toplumsal arka planları sorgulanmaya niyet edilmeyince, araşturmacıda zaman ötesi bir süreklilik çağrışımı yapmışır. Oysa, barınma kültürünün verileri çerçevesinde bakılmış olsaydı, Boğazköy'ün Bizans dönemi konutlarında yaşayanların, yine moloz taş temelli ve kerpiç duvarh olmayı sürdüren bu konutlarda hiç de Hititler dönemindeki gibi barınmadıkları, ısınmadıklan ve üretmedikleri, çok daha kolay fark edilecekti ${ }^{56}$.

Konya yöresindeki Çatalhöyük neolitik yerleşimi ile günümüzde Orta Anadolu'da tespit edilen kerpiç esash geleneksel kırsal yerleşme dokuları fiziksel kurgu açısından ortaklık gösterse de bunların değişik malzeme - işlev örtüşmelerini temsil ettikleri unutulmamalıdır. Örneğin Çatalhöyük'teki hücresel yerleşme dokusu (Şekil 16) yiyeceklerin kurutulduğu düz damlar itibarı ile günümüz ile işlevsel süreklilik gösterirken ölülerin gömüldüğü seki altlanı ve dini inanca dayalı ritüellerin iç mekâna yansımaları konularında tarihsel özgünlüğe sahip "bir yeryüzü ve yer altı katmanlaşması" sergilemektedirler.

Fiziksel kurgunun ortak işlevsel kurgunun ise kültüre göre farkh olduğu örneklerin yanı sıra benzer işlevsel kurguların çevre şartlarına göre farklı fiziksel kurgularla karşılandığı örnekleri de dikkate almak gerekir. Örneğin coğrafi şartlar ve çevresel veriler yerleşik düzende olduğu kadar göçer toplumdaki mekânın fiziksel kurgusunu da etkilemiştir. Fiziksel özellikleri itibar ile Orta Asya'da hasır örgü ve keçe gibi malzemelerden üretilen topak evin Anadolu'ya geçişte çevrenin elverdiği ölçüde korunduğu görülmektedir. Göçebe ve yarı-göçebe olarak Anadolu'ya gelen Türkler öncelikle iklimsel ve topoğrafik olarak Orta Asya bozkırına benzer İç Anadolu platosuyla karşlaştuklan için yanlarında getirdikleri koyun sürüleri yeni çevresel şartlara uyum sağlayabilmiş ve böylece keçe örtülü topak ev tipolojisi fiziksel ve işlevsel boyutlan ile sürdürebilmiştir ${ }^{57}$. Topak evlerin günümüzde Bor (Niğde) Ovası'nda halen kullanılıyor olması ve Afyon, Eskişehir ve Konya yörelerinde bulunabilmeleri bu savı desteklemektedir ${ }^{58}$. Buna karşın Anadolu'nun dağlık, ormanlık ve yağışlı olan kıyı bölgelerinde bu bağlama uyum gösteren keçilerin

${ }^{56}$ Tanyeli, 1996: 405
${ }^{57}$ Bakır, "Toroslarda Göçebe Mimarisi”, s. 17.
${ }^{58}$ Bakır, "Toroslarda Göçebe Mimarisi", s. 17. 
beslenmesi zorunlu olmuştur. Bu değişim ile birlikte keçi kılından yapılarak sudan koruyucu özellik gösteren kara çadırların kullanılmaya başlanması ve yeni malzemenin asma-germe strüktüre uygunluğuyla getirdiği yapı sistemi değişimi mimaride fiziksel kurgunun çevresel şartlara adaptasyonuna iyi bir örnektir (Şekil 7, 8).

Batı Akdeniz Bölgesi'nde yaşayan Sarıkeçili, Karatekeli, Karakoyunlu ve Gebizli Yörüklerince Korkuteli (Antalya), Bucak (Burdur), Anamas (Isparta), Akşehir (Konya), Karaman ve Erdemli (Mersin) yörelerinde kullanılan kara çadırın hammaddesi keçi kılıdır (Şekil 7, 8). Keçi kılının mekânı nasıl dönüştürdüğü incelenmelidir. Bu yapı malzemesi kolay temin edilebilir olması, yapım sistemine kazandırdığı kolaylıklar, yapı elemanı olarak dürülüp katlanmaya imkân tanıması, bünyesinde su tutmayarak çabuk kuruması ve yükte asgari ağırlıkta malzeme ile azami alanı örtme kapasitesi sayesinde tercih edilmiştir ${ }^{59}$. Çadırların örtüsünü ve asma-germe mantığıyla strüktürel sistemini oluşturan modüler birimler (kanatlar) $65-70 \mathrm{~cm}$ eninde ve 4-7 m uzunluğunda olup yan yana dikildikten sonra enine kolan adı verilen dokuma kirişlerle bağlanır. Üst örtü düşey yönde $230-250 \mathrm{~cm}$ yükseklikte ve aşiretlere göre değişen sayıda ahşap direklerle taşınır. Yatay yönde kazıklara bağlanan iplerle yapının stabilitesi sağlanır. İç mekânı istenmeyen çevresel şartlardan korumak için çadır strüktürünün yan kısımlarına $1-1,5 \mathrm{~m}$ aralıklı ahşap kazıklarla desteklenen çı̆ ya da dolak hasırları yerleştirilir. $\mathrm{Bu}$ şekilde çadır az iş gücü ile pratik olarak kurulabilir ${ }^{60}$.

Alaçıklar ise çadırlara kıyasla toprağa daha çok bağımlı yapılardır çünkü kuruldukları yerlerde daha uzun süre ile kalınmaktadır ${ }^{61}$. Alaçık, ağaç dallarının bir uçlarının yere çakılması, diğer uçlarının eğilmesi, bunların da birbirlerine ip ya da ağaç kabuğu lifleriyle bağlanarak yan yana yaklaşık bir metre aralıklar ile dizilmesi ile inşa edilir (Şekil 9). "Eğme" adı verilen bu iskeletin kaburgaları dik yönde $25-30 \mathrm{~cm}$. ara ile yatay çubuklarla bağlanır. Bu işlem ile bağımsız kemerler sürekli bir tonoz haline getirilmektedir. Yapı iskeletinin üzeri keçe, çul, kilim vb. malzemeler ile kaplanır ${ }^{62}$.

${ }^{59}$ Bakır, "Toroslarda Göçebe Mimarisi", s. 19.

${ }^{60}$ Bakır, "Toroslarda Göçebe Mimarisi", s. 19

${ }^{61}$ Haşim Karpuz-İbrahim Bakır, "Türkiye'de İkinci Konut Olarak Yayla, Mezra ve Tatil Evleri," Türkiye Aile Yillı̆ı̆ 1991, T.C. Başbakanlık Aile Araşturma Kurumu, Ankara 1991, s. 301310.

${ }^{62}$ Karpuz - Bakır, a.g.m., s. 303. 
Göçer veya yerleşik özelliklerinden bağımsız olarak mekân kurgusunun belirleyicileri işlevsel şema olduğu kadar temin edilebilen yapı malzemeleri ve bunların inşa için taşıdığı potansiyeldir. Mekân kurgusu doğrudan fiziksel kurguya, bir başka deyişle, yapı malzemelerinin potansiyellerine ve yapısal bir bütünlük oluşturmak üzere bir araya geliş biçimlerine bağlıdır. Örneğin Konya Ovası ile Akdeniz kıyılanı arasında yer alan Batı Toroslar'daki Akseki-İbradı Havzası'na has malzeme ve teknik özellikleri içeren fiziksel kurgu bu duruma iyi bir örnektir (Şekil 17). Geleneksel çevreye mimari karakterini veren fiziksel olgular, yerel malzemelerin tutarlı bir yapı oluşturmak üzere bir araya geliş biçimleridir. Topak ev, kara çadır, yerleşik düzendeki kır evi (Şekil 1, $2,7,8)$ gibi örneklerin ortak noktası fiziksel kurgunun temel biriminin oluşum mantığıdır. Bu birim çevrenin sunduğu malzemelerden mimari kültür aracilı̆ıyla oluşturulan bileşim detayıdır. Bu detay çevrenin fiziksel yapısından parçaların yeniden organize edilmesinin gereği olarak, topak evde hasır örgü ve keçe (Şekil 1,2) , karaçadırda keçi kılının asma-germe potansiyeli (Şekil 7,8 ), alaçıkta yassiltılan ve eğilen ağaç dallarının gerilmeye karşı dayanımı (Şekil 9) üzerinden kurgulanan çerçeve sistemi, Akseki evinde ise (Şekil 17) ahşap ve taş birlikteliği ile vücut bulur.

Akdeniz ve Karadeniz kıyısındaki kırsal konut mimarisi örneklerinin Anadolu antik gelenekleri ile süreklilikleri ortaya konabilmektedir (Şekil 6, 13, 14, 15). Tarih boyunca benzer çevresel şartlarda benzer yapı sistemlerinin kullanılması tesadüf değildir. Fakat günümüzdeki örneklerin işlev ile birlikte fiziki yapısında da özgünlükler olduğu anlaşılmaktadır. Türklerin Anadolu'da sürdürdükleri transhümans ve mimarisi antik Anadolu yapı gelenekleriyle göçer / yarı göçer yaşamın başarılı bir sentezini yansitır.

Yaylak - kışlak üzerine kurulu ikili yaşam kalıbı ve bunların mekâna yansıması Anadolu - Türk kültür tarihinde önemli bir yere sahip olsa da bu konuda az sayıda akademik çalışma yapılmışı ${ }^{63}$. Yerleşik düzen yapılanı arasında güzergah ve hareket takvimleri tanımlı özgün bir transhümansin bulunduğu Doğu Karadeniz'de mevsimsel göç kışlak - mez-

${ }^{63}$ Karpuz - Bakır, a.g.m., s. 301-302.

Yayla hayat Türk kültür tarihinin bir çok boyutunda öneme sahiptir. Yayla hayat türkülere ve destanlara konu olmuştur. Aynca yaylalara göçler ve yayla dönüşleri gelenekselleşmiş şenlikler ile gerçekleşir. Göş güzergahlan tanımlıdır. Örneğin Silifke'de kışlaktan (köyden) "yaz yurduna" göçülür. Burada bir-iki ay kalındıktan sonra hayvanların otlayabileceği alanlar içeren yaylaya göçülür. 
$\mathrm{ra}^{64}$ - yayla noktaları arasında gerçekleşir. Trabzon ve Rize'de zemin katta ahır, üst katta mutfak ve yaşam birimleri olan mezra evlerine Nisan - Mayıs aylarında kalınır buradaki otlaklardan faydalanıldıktan sonra Haziran'da yaylaya çıkılır ve Eylül sonuna kadar kalınır. Kışlağa dönüş tekrar mezra üzerinden yapılır. Bazı kırsal yerleşimlerde ise transhümans hayvancılığa değil tarımsal üretime bağlıdır. Bu durumda yazlık evler "bağ evleri” adını alır. Örneğin Batı Toroslar'da İbradı'daki Ürünlü ve Gödene köylerinin yer aldığı Manavgat Irmağı havzasındaki ani topografik değişim ve su kaynaklarının bolluğu çok yakındaki kışlık köy merkezinden çok daha elverişli şartlarda tarımsal üretim yapılmasını sağlamışır. Öyle ki kışlık ve yazlık konutlar (bağ evleri) arasındaki uzaklık $5-10 \mathrm{~km}$. bandında yer almışır. Bu yerleşme kalıplarındaki bağ evlerinde teras, köşk, ayazlık vb. fiziksel kurgu elemanlarının işlevsel şemaya göre sıklaşması, araziye daha çok yayılması ve yapının şeffaflaşması söz konusu olmuştur (Şekil 18).

Yukandaki örneklerin de gösterdiği gibi fiziksel kurgu kültür ve çevreye özgü değerlerle birlikte şekillenmiştir. Benzer fiziksel kurgular farkh yaşam biçimlerini barındırabilmektedir. Fakat her durumda çevreyi şekillendirme tarzının arkasında yatan temel anlayıs mimari detayda vücut bulmaktadır. Başka türlü zayff ve dağılabilir nitelikte olan yerel malzemeler fiziksel kurgu sayesinde dayanıklı ve kalıı bir yapıya dönüşür. Yörenin doğal karakteriyle birlikte bu karakterin kültüre özgü yorumu fiziksel kurguda kodlanmıştır. Fiziksel kurgunun açıklanması mimarinin kültürel içeriğinin keşfedilmesi için önemli bir adımdır.

\section{SONUÇ}

Türk evinin tarihsel kökenleri her zaman tartı̧̧maya açı olmuştur. Günümüzde Anadolu'da halen kullanılmakta olan geleneksel konutların Orta Asya kültürü ve antik Anadolu kültürleriyle ilişkileri konusunda tarihin derinliklerinden elde edebildiğimiz malzemeler kesin yargilara varmak için yetersizdir. Bununla birlikte araştırma malzememizin genel nitelikleri Orta Asya ve Anadolu'daki Türklerin barınma biçimleri ve yapı üretim süreçleri arasında bir süreklilik bulunduğunu doğrulamaktadır. Güç olan ise bu ilişkinin karakteri hakkında kesin yargılarda bulunmaktur.

${ }^{64}$ Karpuz - Bakır, a.g.m., s. 306.

Mezra, kışlık yerleşim ile yayla arasında yer alan, Nisan - Mayıs gibi ilkbahar aylarının geçirildiği, tarım ve hayvanclığa uygun çevresel şartlara sahip yerleşim yeridir. Mezralarda ikamet süreleri ve buradaki konut biçimleri bölgelere göre çeşitlilik gösterir. 
Hiçbir kültürün katıksız ve saf olmadığının sosyal bilimlerde tarihsel verilerle kantlandığı günümüzde mimarlık tarihinde de çok yönlü etkileşimleri dikkate almak kaçınılmazdır. Orta Asya-Anadolu sürekliliğini tesis eden ilkeleri sağlıkı bir şekilde değerlendirebilmek için asırları kapsayan karmaşık bir süreci basitleştirmekten kaçınmak, bunun yerine daha çok zaman üstü mekânsal ilkelerin şematik düzeyde sürekliliklerine odaklanmak daha doğrudur. Bunu yaparken Anadolu'da tespit edilen geleneksel Türk konutlarının salt Orta Asya kökenlerine veya salt antik Anadolu geçmişine indirgenmesi bilimsel görünmemektedir. Tarihsel veriler Anadolu'daki geleneksel Türk konutlarının hem Orta Asya'da hem de Anadolu'nun 11-12. yüzyıllar öncesindeki geçmişinde temellendirilebileceğini göstermektedir. Aynı zamanda Anadolu'nun coğrafi konumu bölgeyi "Akdeniz coğrafyası" gibi farklı tarihsel bütünlüklerin de bir alt kümesi haline sokmaktadır ${ }^{65}$. Bu bağlamda Anadolu mimari geleneklerinin Akdeniz coğrafyasındaki ülkeler ile sürekliliklerinden söz etmek de mümkündür.

Şimdiye kadar pek çok araştırma konu hakkında öneriler getirmiştir. Yeni bulguların yeni tartısmaları beraberinde getireceği açıktır. Tarih boyunca konutlar anıtsal yapıların aksine, dayanıksız ve geçici malzemelerden yapılmışlardır. Bu nedenle sivil mimari tarihi konusunda hiçbir zaman tatmin edici düzeyde veriye ulaşlamayacağı da ortadadır. Tarihsel verilerin bu özelliklerinden dolayı buradaki çalışma konu hakkında kesin bir yargı veya son bir söz ortaya koyma iddiasıı taşımamaktadır. Burada güncel bulgular çerçevesinde konuyla ilgili öne çıkan farklı görüşler özetlenerek tekrar sorgulanmıştır. Bu görüşlerin getirdiği eleştirel altyapıdan faydalanarak konu önyargılardan uzak bir şekilde ve bilimsel yöntem ışığında incelenerek işlevsel ve fiziksel boyutlarıyla ele alınmıştır.

Netice şu şekilde özetlenebilir:

Değişik coğrafyalarda değişmeden aktarılan mekânsal kurgulardan bahsetmek mümkün değildir. Örneklerle ortaya konduğu gibi daha çok kültüre dayalı işlevsel boyutuyla korunan mekân, fiziksel planda çevreyle değişen yapı malzeme ve sistemleriyle somutlaşmıştır. Dolayı-

${ }^{65}$ Alisa Ginio, “Akdeniz Düşüncesi: Henri Pirenne, Shelomo Dov Goitein ve Fernand Braudel", Akdeniz Dünyast: Düsüunce, Tarih, Görünüm (editör: E. Özveren, O. Özel, S. Ünsal, K. Emiroğlu) İletişim Yayınlan, İstanbul 2006. 
sıyla sabit bir mimari "tip" ortaya koyarak kökenler arandığında tarihsel veri azlığı nedeniyle karmaşık tarihsel gelişim basitleştirilmektedir. Bu basitleştirmeyi yapmadan işlev şemasındaki soyut mantığın sürekliliğini aramak ve daha çok çevreyi yorumlama, çevreye getirilen topyekûn yaklaşım temelinde benzerliklerin kurulması, form ve malzemeye dayalı genellemelerden mümkün olduğunca kaçınılması gerekir. Bunun sebebi mimarlık tarihinin konusu olan form ve malzemelerin insanoğlunun ortak mirası olması ve benzer biçimsel ve yapısal özelliklerin çok farklı kültürlerde tekrarlanmasıdır (Şekil 1, 9, 10, 13, 14, 15).

Dolayısıyla mimaride kültürel özgünlüklerin aranması noktasında esas incelenmesi gereken bir mimari kalıbı oluşturan bağlam - problem - çözüm çakışması ya da işlev - form - teknik çakışmasıdır. Mekân kurgusunda işlev - malzeme örtüşmeleriyle kültüre özgü nitelikler, kültürel yaklaşımları ve çevre duyarlıkları açığa çıkacaktır. Bu çerçevede seçilen örnekler çeşitlendirildiğinde yeni soruların sorulması ve çalışmaların zenginleşmesi mümkün olacaktır.

\section{KAYNAKÇA:}

Acar, Erhan, “Anadolu'da Tarihöncesi Çağlardan Tunç Çağı Sonuna Kadar Konut ve Yerleşme", Tarihten Günümüze Anadolu'da Konut ve Yerleşme - T.C. Başbakanlık TOKI II. B.M. Insan Yerlesimleri - Habitat 1996 Konferansi Bildiriler ve Sergi Kitabi (1996), s. 380-394.

Alexander, Christopher vd., A Pattern Language: Towns, Buildings, Construction, Oxford University Press, New York 1977.

Aran, Kemal, Barnaktan Öte: Anadolu Kir Yapılan, Tepe Mimarlık Kültürü Merkezi, Ankara 2000.

Arel, Ayda, Osmanl Konut Geleneğinden Tarihsel Sorunlar, Ege Üniversitesi Güzel Sanatlar Fakültesi Yayınları No:11, İzmir 1982.

Bakır, İbrahim, "Toroslarda Göçebe Mimarisi”. T.C. Kültür Bakanlı̆ı Halk Kültuirünü Arastrma Dairesi Yaynlar: 148 - Türk Halk Mimarisi Sempozyumu Bildiriler Kitabl, 1990, s. 17-30.

Bakır, İbrahim, "Teke Yöresi Konutlarında Yaşatılan Selçuklu Mimarlık Gelenekleri". T.C. Antalya Valiliği Yayınlan IV. Selçuklu Semineri Bildiriler Kitabi, Antalya 1992, s. 11-24.

Bakır, İbrahim, Batı Toroslarda Gọ̈erlerin Yerleşme ve Mekân Sorunlarnnn Çözümü Uzzerine Bir Deneme (Yayınlanmamış Doktora Tezi) Selçuk Üniversitesi, Konya 1995. 
Bammer, Anton, "Çadır ile Anadolu Evi İlişkileri," Tarihten Günümüze Anadolu'da Konut ve Yerlesme - T.C. Basbakanlik TOKI II. B.M. Insan Yerlesimleri Habitat 1996 Konferanst Bildiriler ve Sergi Kitabı (1996), s. 234-247.

Carter, Thomas ve Cromley Elizabeth C., Invitation to Vermacular Architecture, A Guide to the Study of Ordinary Buildings and Landscapes, The University of Tennessee Press, Knoxville 2005.

Cezar, Mustafa, Anadolu Öncesi Türklerde Şehir ve Mimarlk, Türkiye İş Bankas1 Yayınları, İstanbul 1977.

Ching, Francis D.K., Jarzombek Mark ve Prakash Vikramaditya, A Global History of Architecture, John Wiley \& Sons, New Jersey 2007.

Deleuze, Gilles ve Guattari Félix, A Thousand Plateaus: Capitalism and Schizophrenia, çev. Brian Massumi, University of Minnesota Press, Minneapolis - London 1987.

Deniz, Bekir, “Orta Asya'daki Eski Türk Evleri,” Akdeniz Universitesi Güzel Sanatlar Fakültesi Akdeniz-Sanat Dergisi I, Antalya 2008, s. 17-51.

Erzen, Jale, Çevre Estetiği. ODTÜ Yayıncılık, Ankara 2006.

Fernie, Eric, "Introduction: A History of Methods," Art History and Its Methods: A Critical Anthology, Phaidon, Hong Kong 1995, s.10-21

Fletcher, Bannister, A History of Architecture on the Comparative Method, Scribner, New York, 1963.

Ginio, Alisa, "Akdeniz Düşüncesi: Henri Pirenne, Shelomo Dov Goitein ve Fernand Braudel", Akdeniz Dïnyast: Dïsü̈nce, Tarih, Görünüm (editör: E. Özveren, D. Özel, S. Ünsal, K. Emiroğlu) İletişim Yayınlan, İstanbul 2006.

Karpuz, Haşim - Bakır İbrahim, "Türkiye'de İkinci Konut olarak Yayla, Mezra ve Tatil Evleri," Türkiye Aile Yillığı 1991, T.C. Başbakanlık Aile Araşturma Kurumu, Ankara 1991, s. 301-31.

Kavas, Kemal Reha, "Sanat Tarihi - Mimarlık Tarihi Arasındaki Değişen İlişkilerin Sivil Konut Mimarisi Araştırmaları Bağlamında Değerlendirilmesi," Akdeniz Üniversitesi Güzel Sanatlar Fakültesi Akdeniz-Sanat Dergisi IV, s. $37-46$.

Kostof, Spiro, A History of Architecture: Settings and Rituals, Oxford University Press, New York 1985.

Kostof, Spiro, "Junctions of Town and Country," Dwellings, Settlements and Tradition: Cross-Cultural Perspectives, University Press of America, Lanham - New York - London 1989. 
Kuban, Doğan, Anadolu-Türk Mimarisinin Kaynak ve Sorunlan, İTÜ Mimarlık Fakültesi Yatunları, İstanbul 1965.

Kuban, Doğan, The Turkish Hayat House, M.T.R., İstanbul 1995.

Küçükerman, Önder, Kendi Mekânınn Arayış Iç̧inde Tiurk Evi, Turing Kurumu, İstanbul 1996.

Naumann, Rudolf, Eski Anadolu Mimarlğ̆, Türk Tarih Kurumu, Ankara 1991.

Norberg-Schulz, Christian, The Concept of Dwelling: on the Way to Figurative Architecture, Rizzoli International Publications, New York 1985.

Payne, Alina, "Architectural History and the History of Art: A Suspendend Dialogue," Joumal of the Society of Architectural Historians, 58: 3 (1999), s. 292-299.

Sey, Yıldız, “Giriş: Bir Sergi Hazırlamak," Tarihten Günümüze Anadolu'da Konut ve Yerlessme - T.C. Başbakanlık TOKİ II. B.M. Insan Yerleşimleri - Habitat 1996 Konferansı Bildiriler ve Sergi Kitabı (1996), s. xix-xxiv.

Tanyeli, Uğur, “Anadolu'da Bizans, Osmanlı Öncesi ve Osmanh Dönemlerinde Yerleşme ve Barınma Düzeni," Tarihten Günümüze Anadolu'da Konut ve Yerleşme - T.C. Başbakanlık TOKİ II. B.M. İnsan Yerleşimleri Habitat 1996 Konferansi Bildiriler ve Sergi Kitabı (1996), s. 405 - 471. 


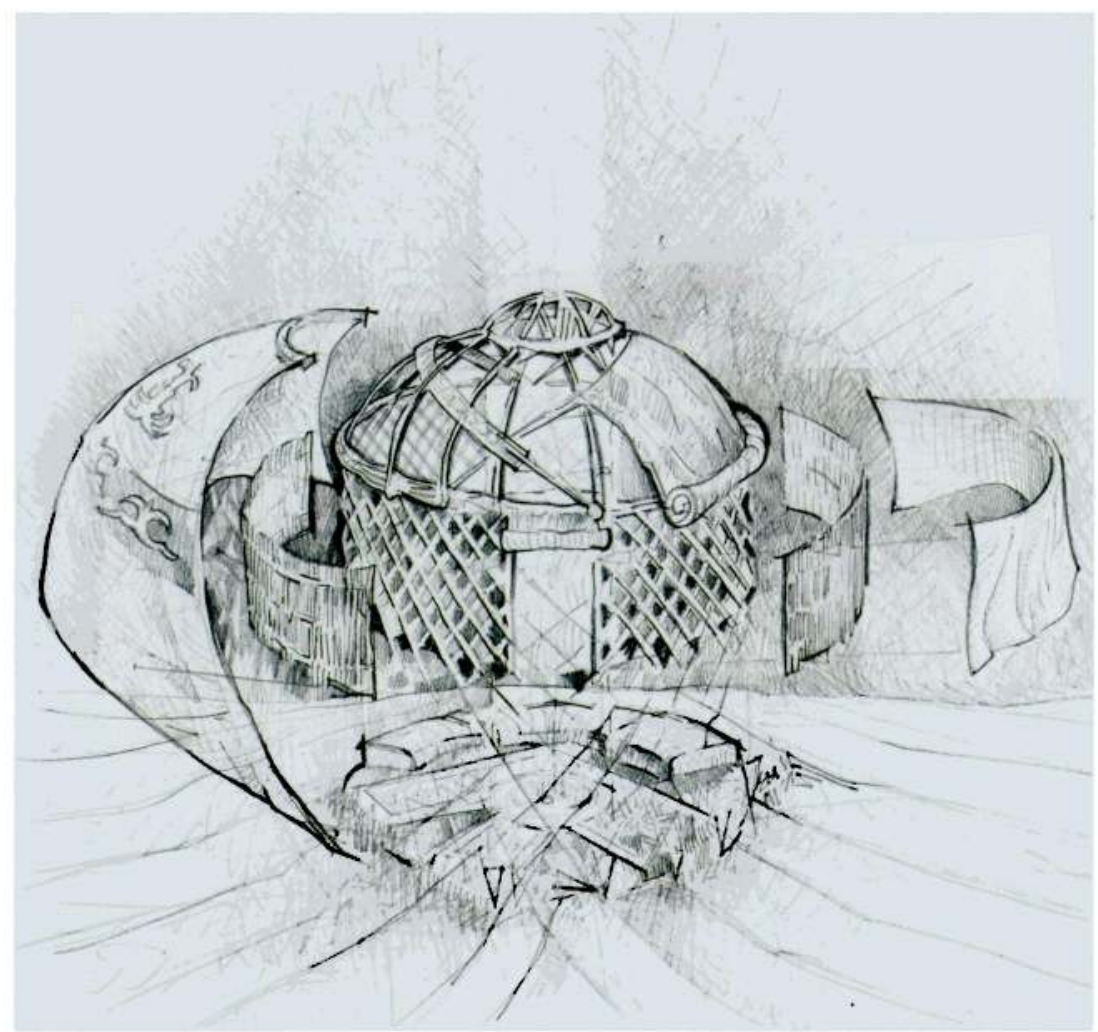

Şekil 1 - Yurt ve mekân tanımı: çevreyle ilişkiler, mekan düzeni, yapısal elemanlar ve örtü elemanlarını gösteren patlatılmış aksonometrik perspektif (çizim: K.R. Kavas)

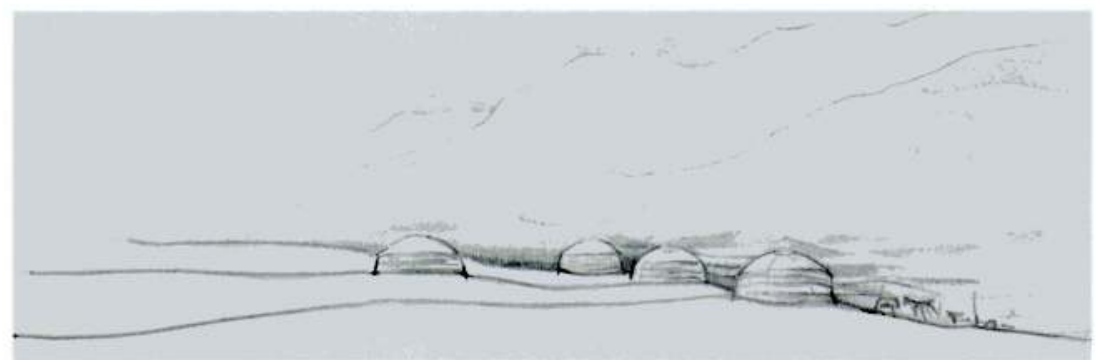

Şekil 2 - Çevrenin mekansallaşması, Türkistan - Kazakistan (çizim: K.R. Kavas) 
Kemal Reha Kavas

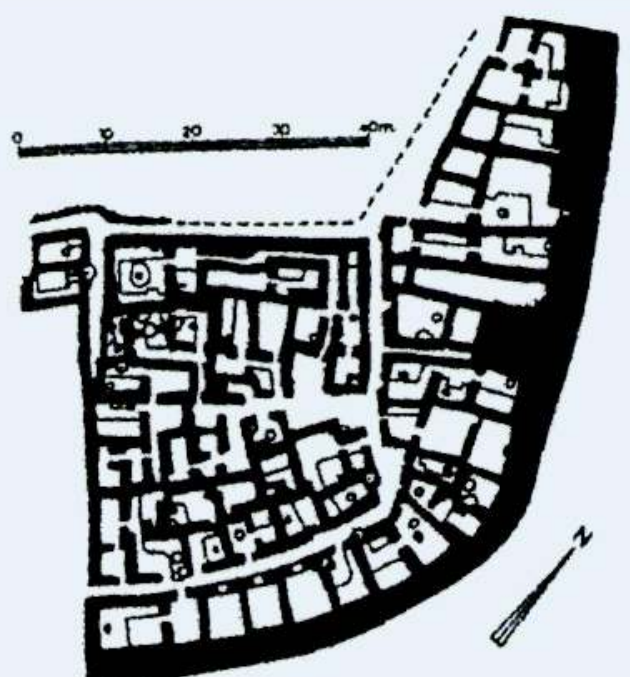

Şekil 3 - Kuyrıktöbe (Kazakistan), evlerin bir sokak üzerinde yerleşme düzeni (B.Deniz, 2008, s.28 / K.M. Baypakov, Z.Ş. Şardenova, S.Y. Pergudova)

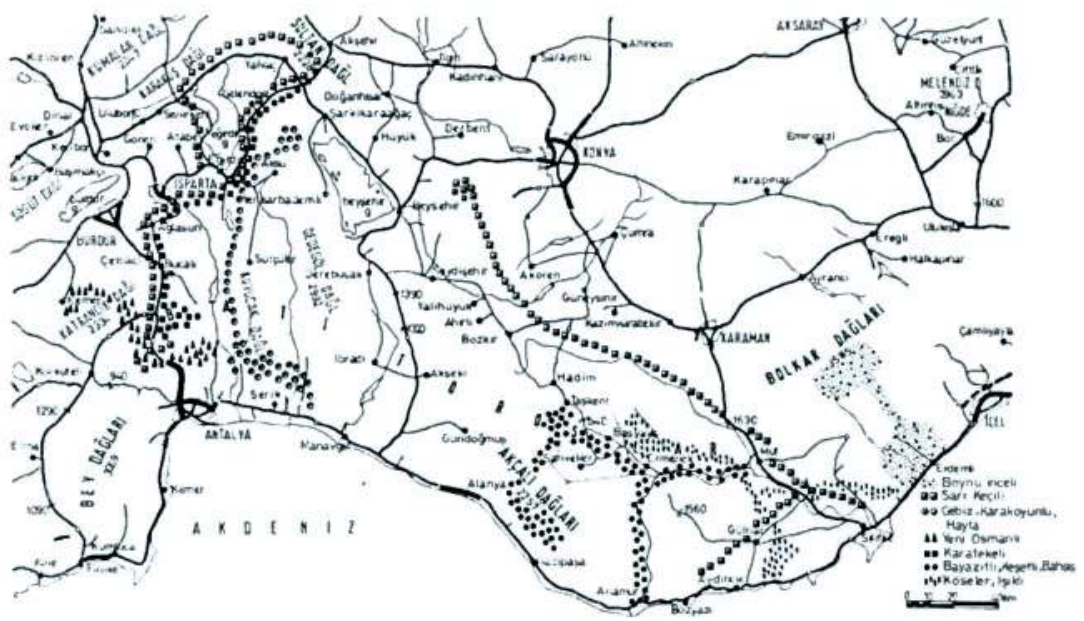

Şekil 4 - Bat Akdeniz Bölgesi (Türkiye) göçerlerinin günümüzdeki hareket güzergâhları (í. Bakır, "Toroslarda Göşebe Mimarisi", s.76) 

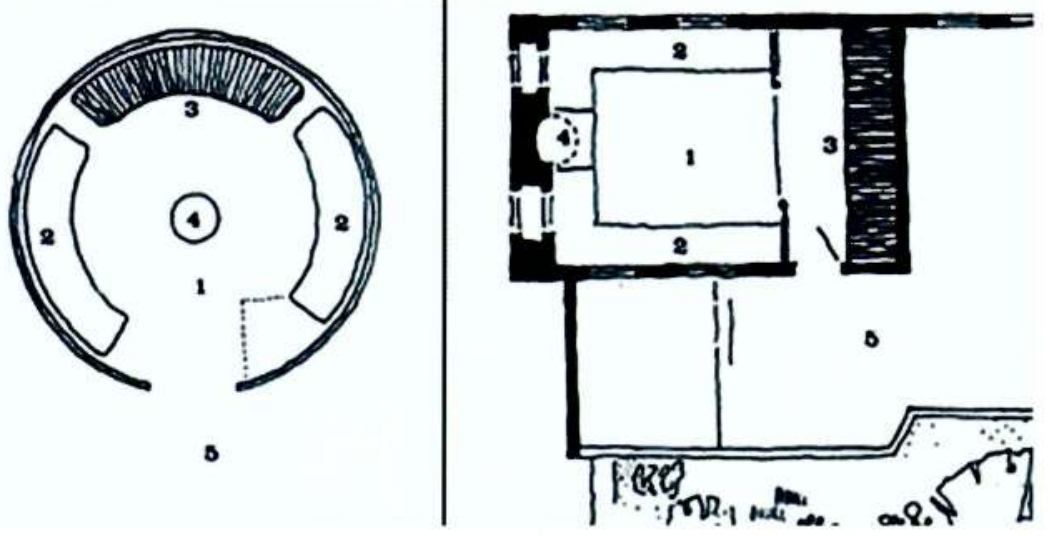

Şekil 5 - İşlevsel kurgu: Türk Evi'nde oda düzeni ile gösche çadır düzeni karşılaştırması (Küçükerman a.g.e, s. 68)

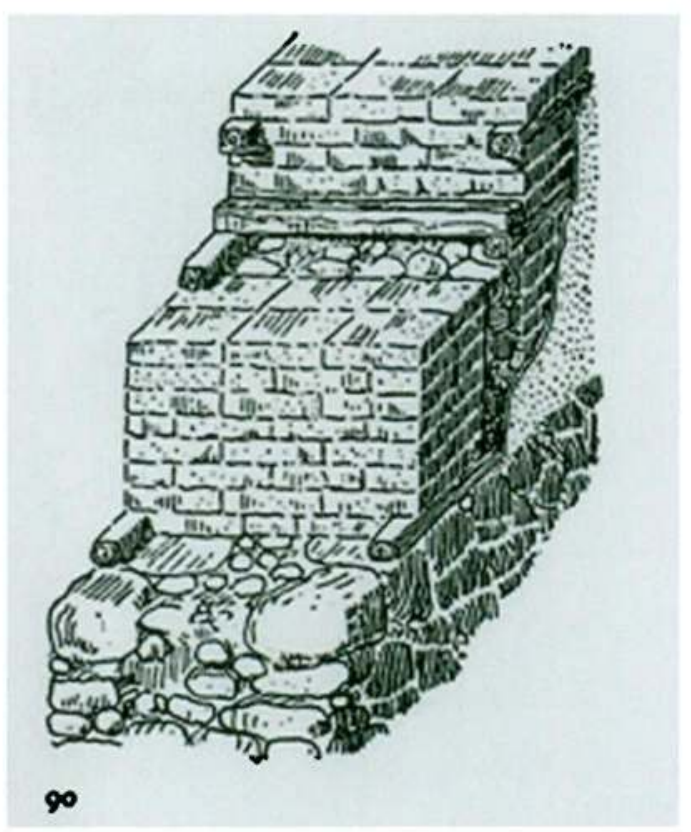

Şekil 6 - Fiziksel Kurgu: Boğazköy, Yapı-E, taş temel üzerindeki ahşap hatillı kerpiç yapının rekonstrüksiyonu (Naumann, a.g.e., s. 100) 


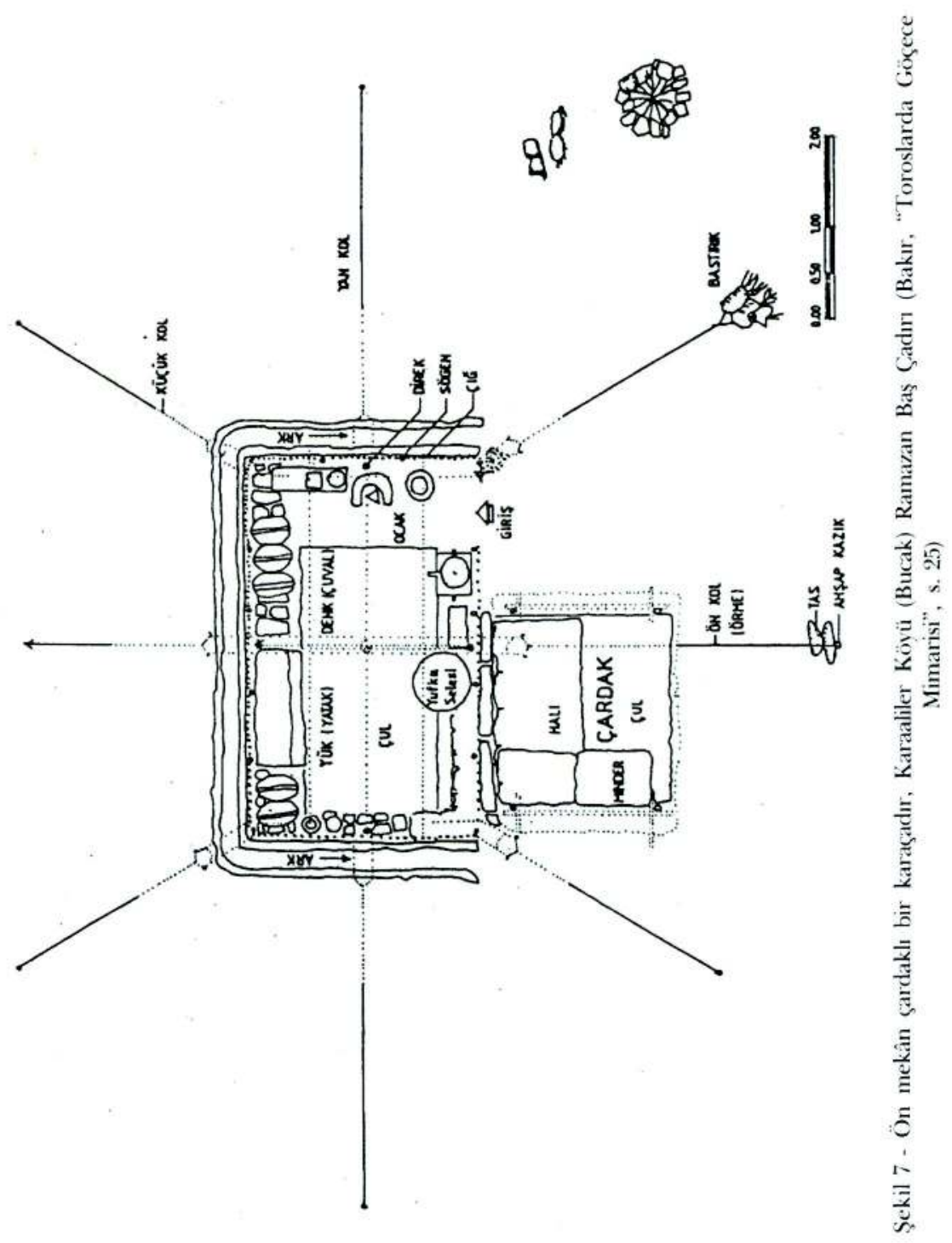


Kemal Reha Kavas

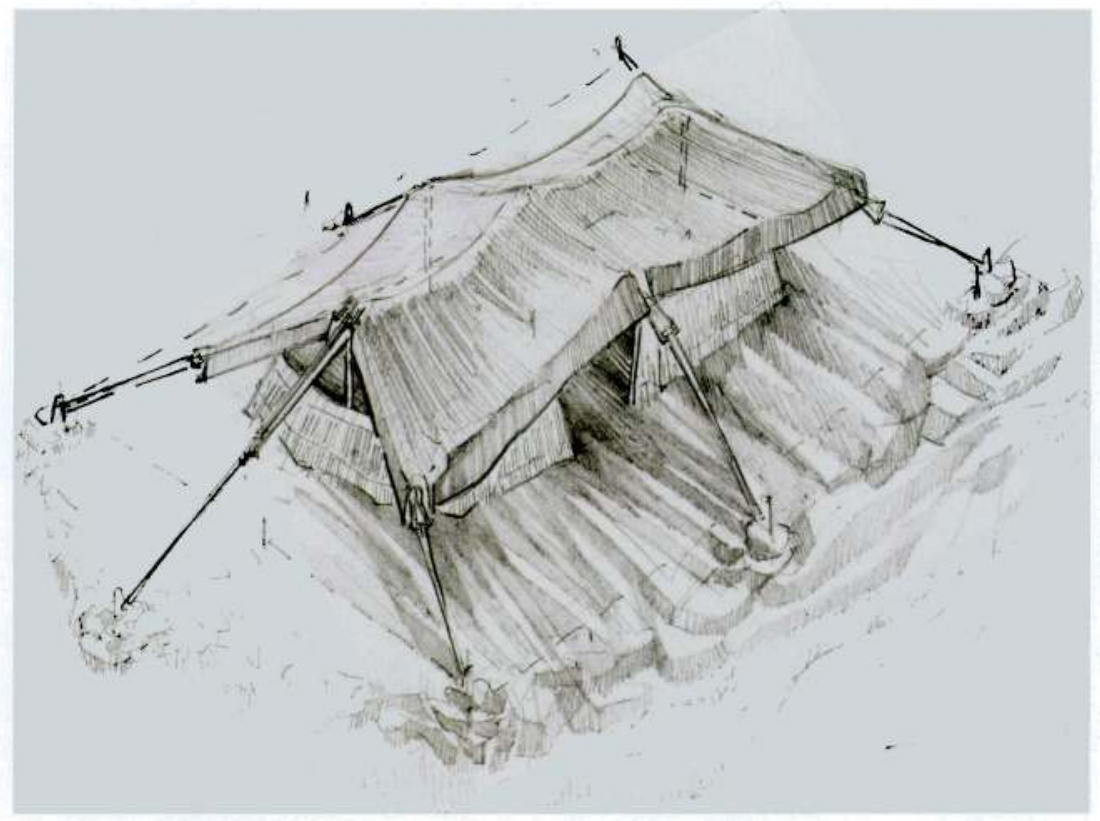

Şekil 8 - Karaçadır: mekan tanımı ve fiziksel kurgu (çizim: K.R. Kavas)

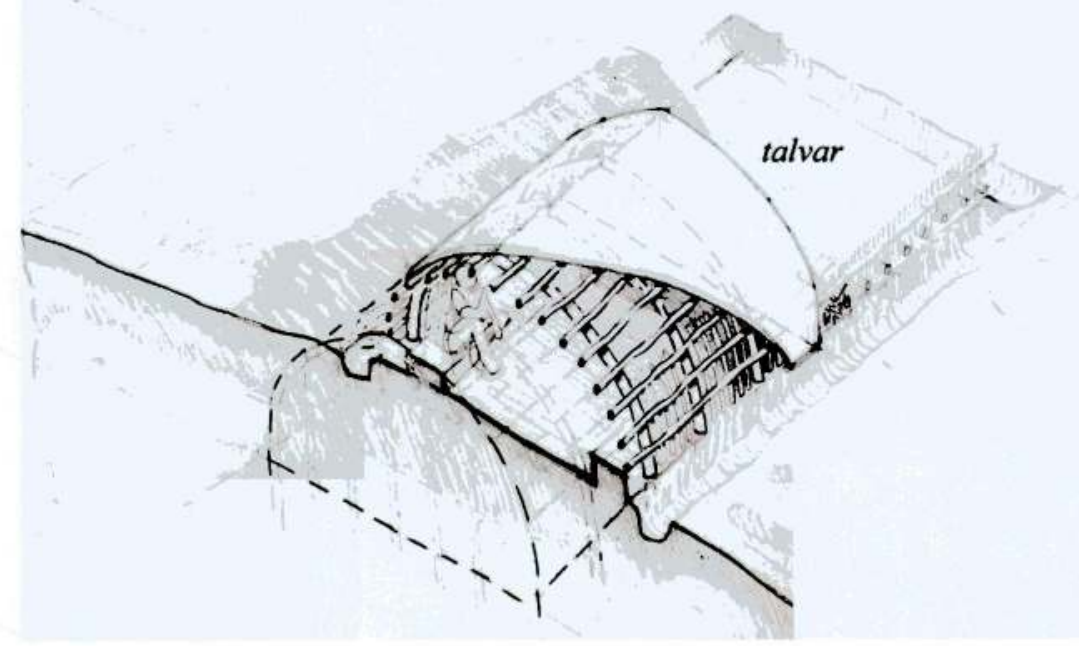

Şekil 9 - Alaçik: mekân tanımı, fiziksel kurgu ve talvar (çizim: K.R. Kavas) 
Kemal Reha Kavas

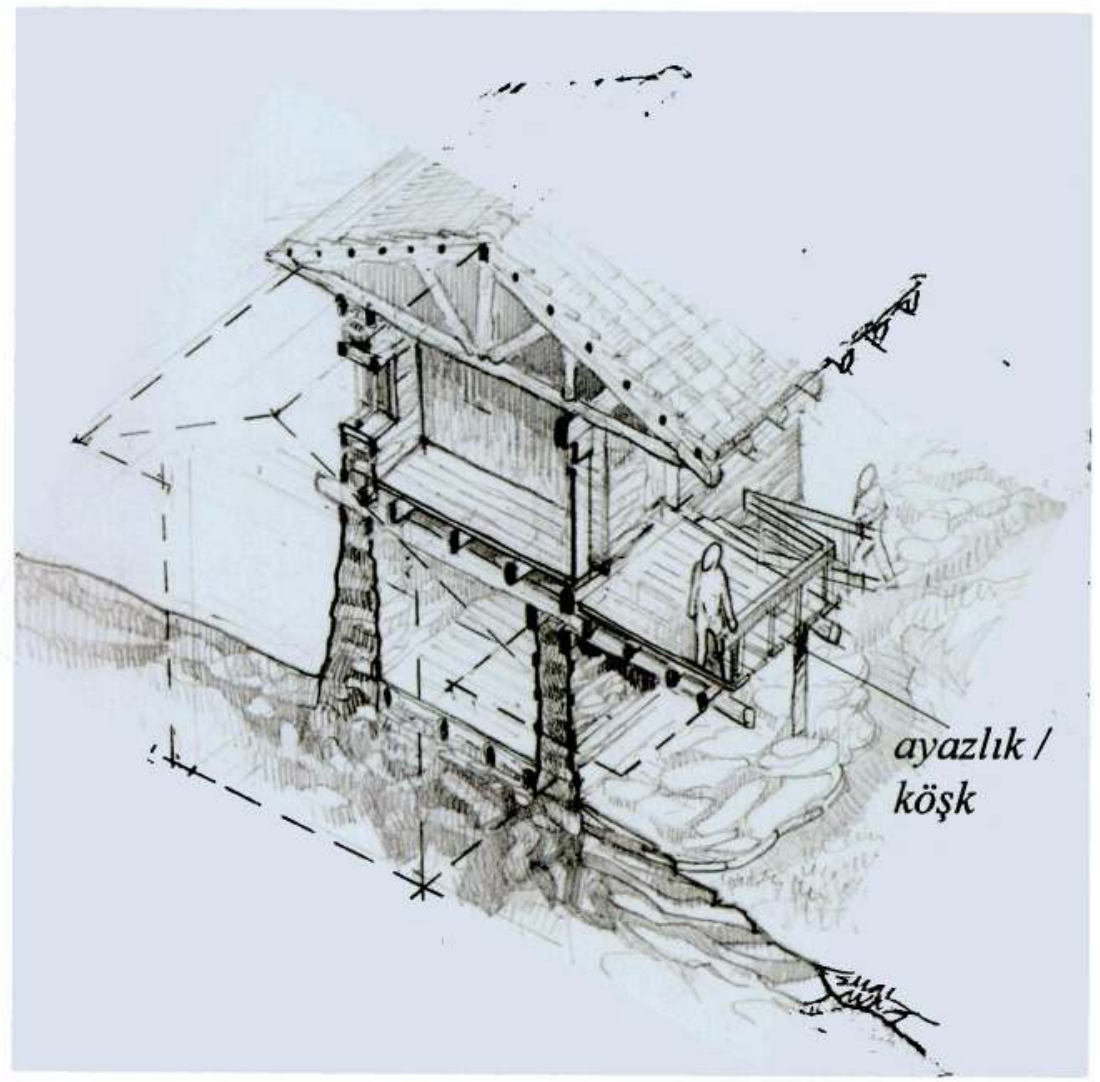

Şekil 10 - Yerleşik düzende ayazlık / köşk (çizim: K.R. Kavas) 


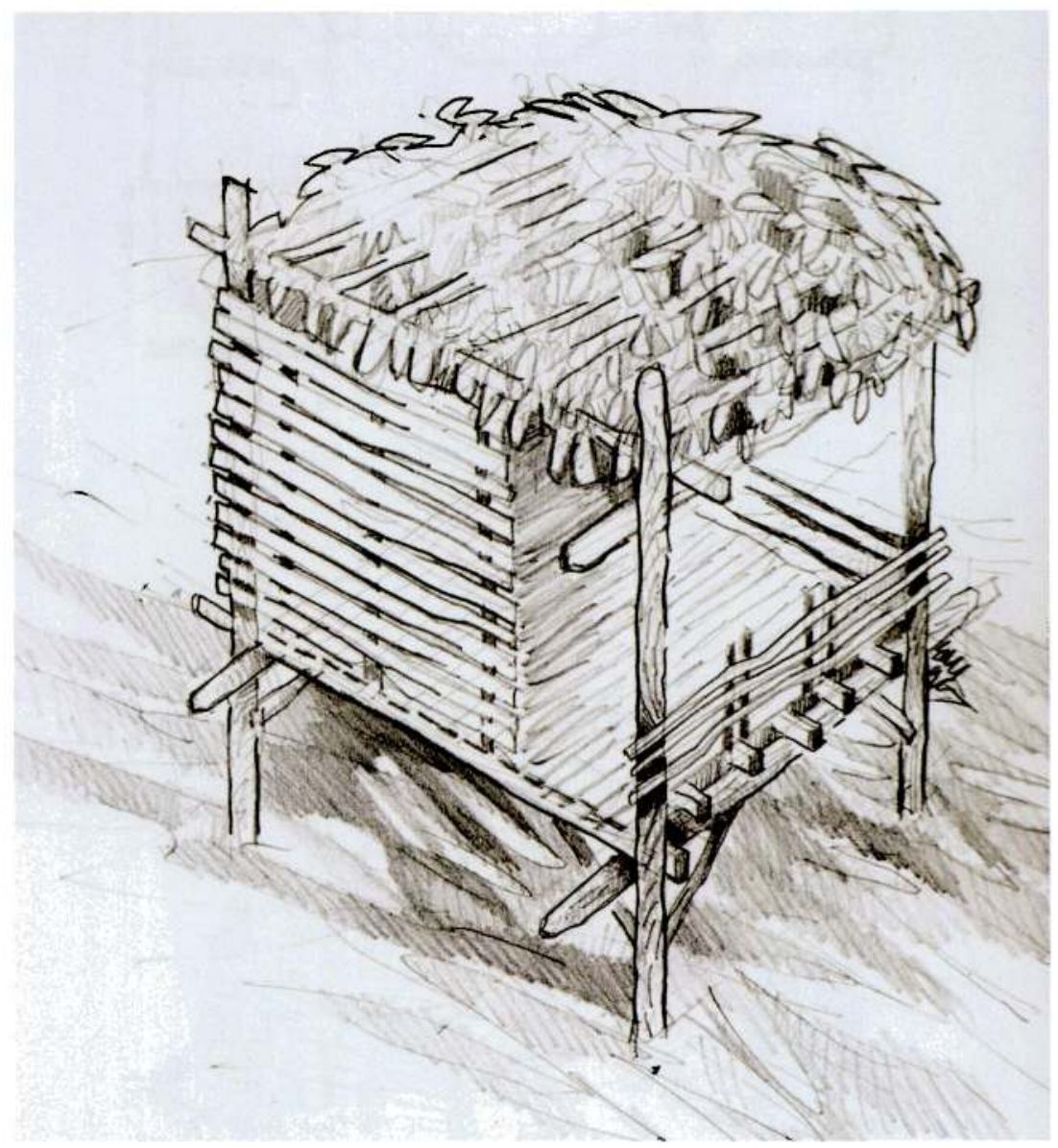

Şekil 11 -Aç̧klık - kapallık düzeyleri yön ve işleve göre belirlenen yükseltilmiş çardak (çizim: K.R. Kavas) 


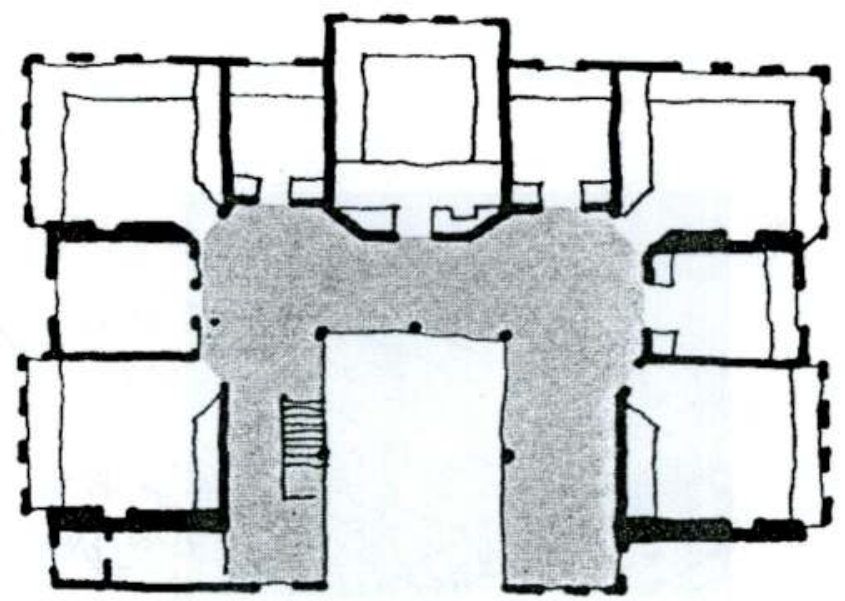

Şekil 12 - Anadolu'nun sıcak iklim bölgesinde kurulan Türk evi (Küçükerman, a.g.e., s. 203)

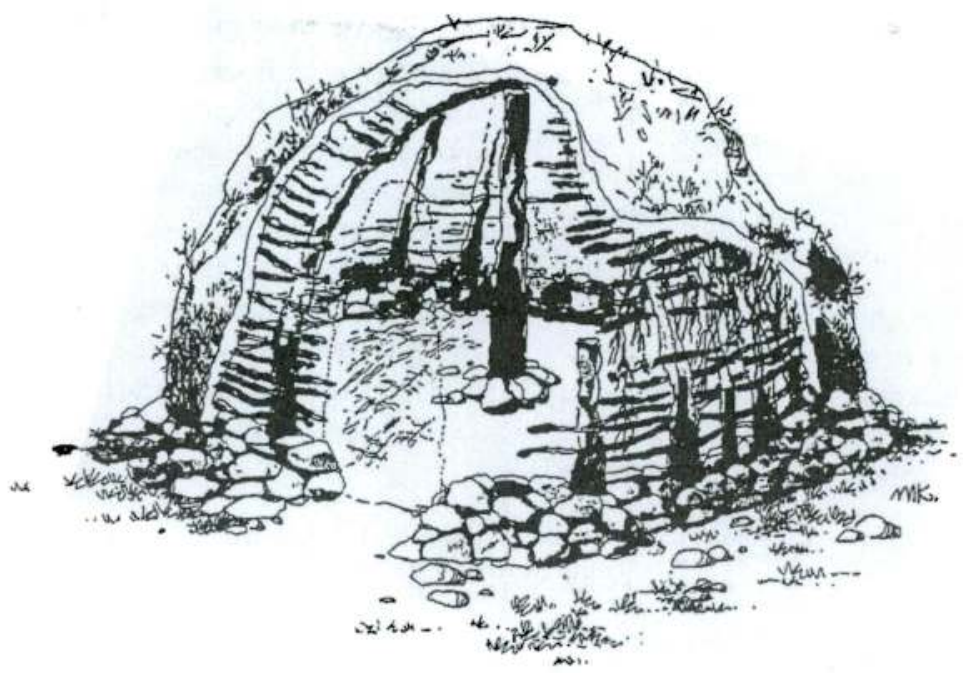

Şekil 13 - Daire formlu erken Neolitik dönemi konutlan, Çayönü - Diyarbakır (Acar, a.g.m., s. 382 - desen: M. Keskin) 
Kemal Reha Kavas

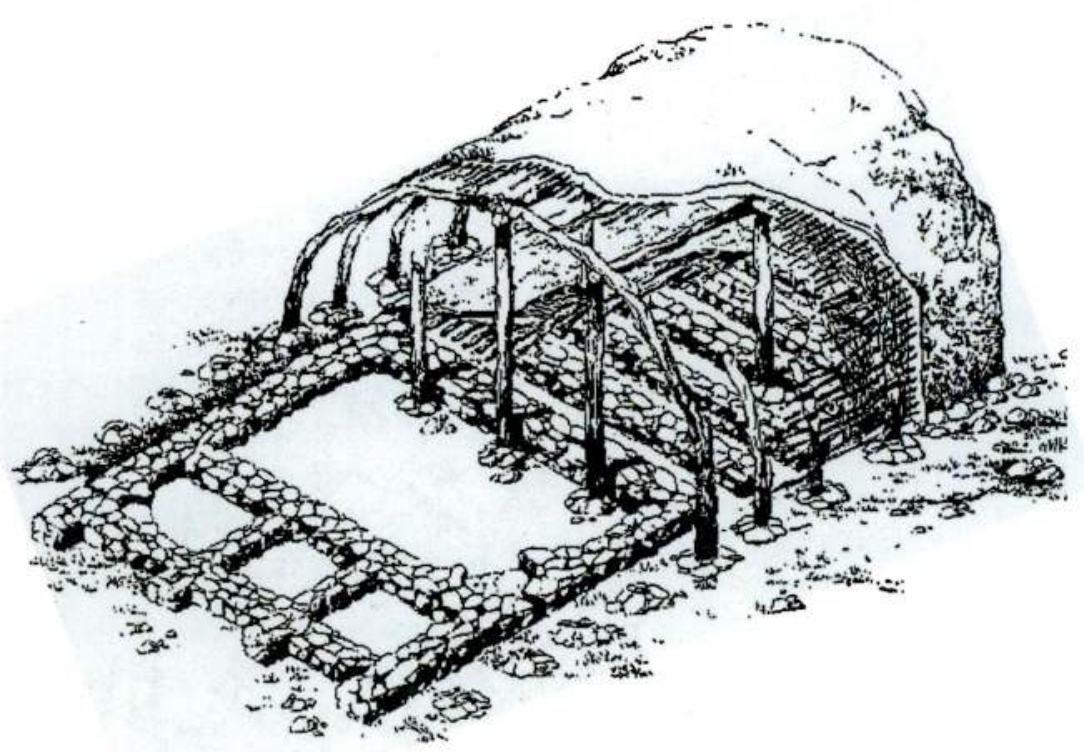

Şekil 14 - Neolitik dönemde Dörtgen formlu konut biçimine geçişi temsil eden ve taş temel üzerinde dal örgü ve çamur sıva ile teşkil edilen konut, Çayönü - Diyarbakır (Acar, a.g.m., s. 383 - desen: M. Keskin)

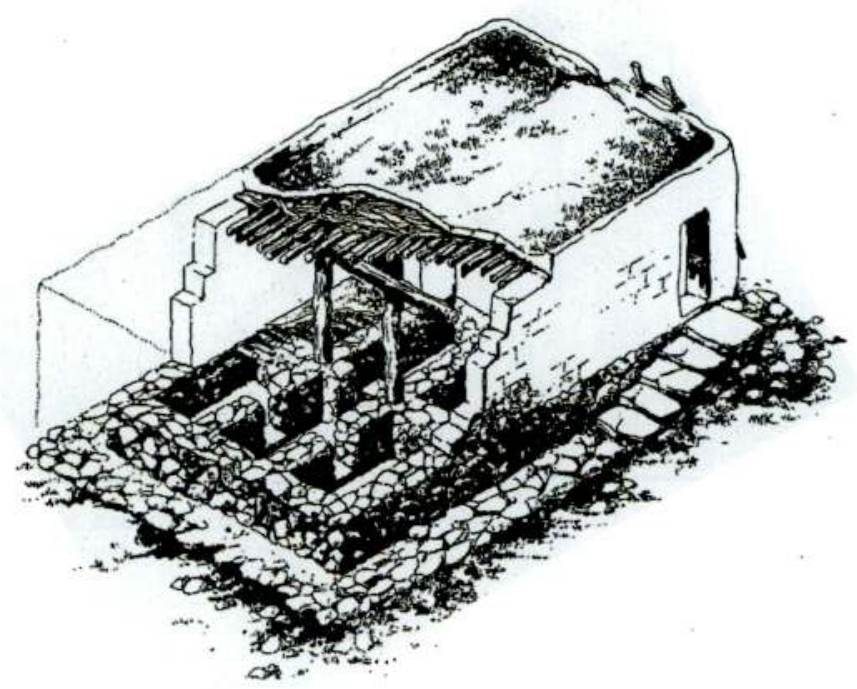

Şekil 15 - Düz duvar ve düz damlı dörtgen plan formlu konut, Çayönü - Diyarbakır (Acar, a.g.m., s. 383 - desen: M. Keskin) 
Kemal Reha Kavas

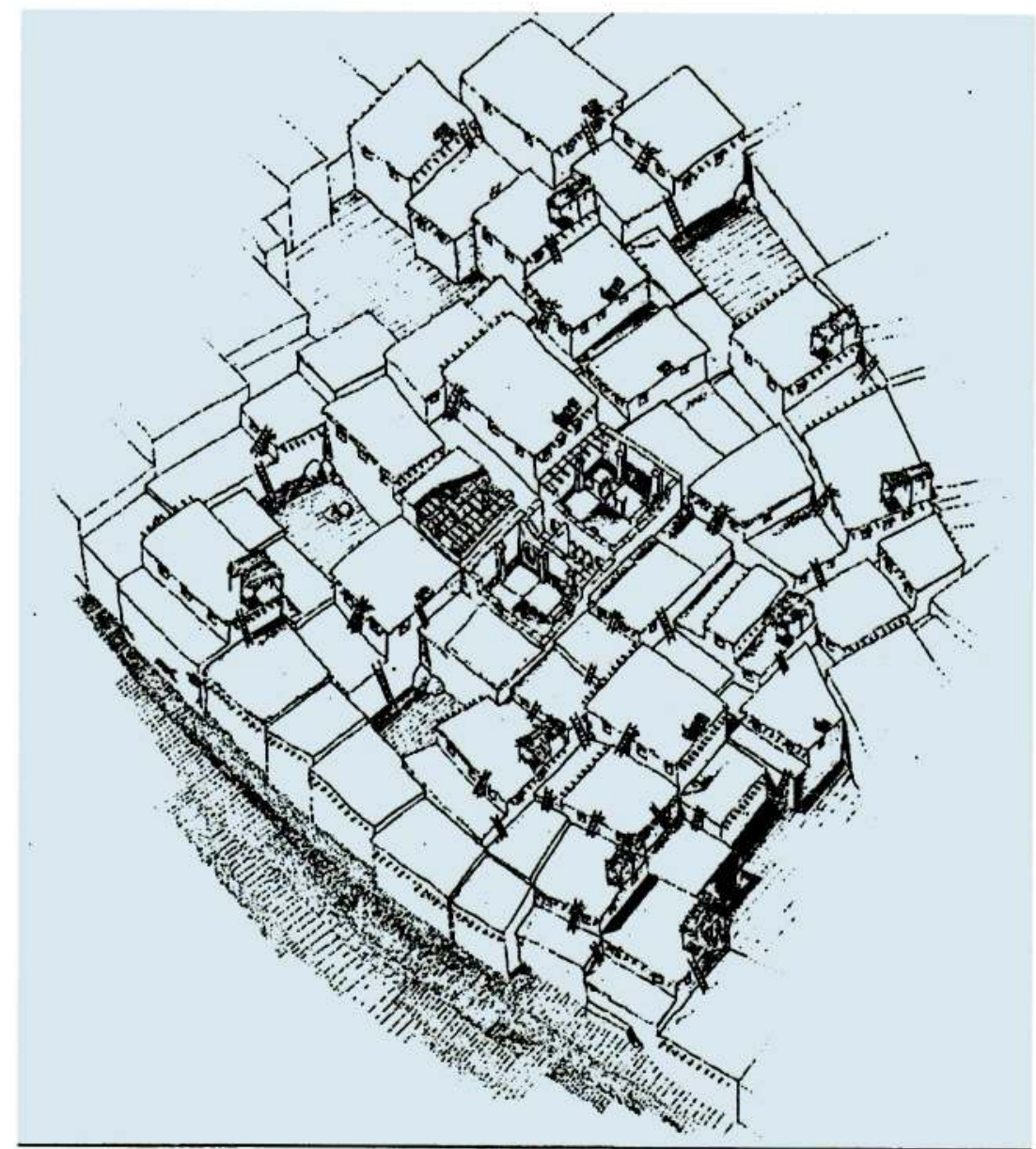

Şekil 16 - Düz daml, damdan girişli, birbirine bitişik konutlardan oluşan hücresel yerleşme dokusu, Çatalhöyük - Konya (Acar, a.g.m.,s. 387 - desen: S.A. Köknar) 
Kemal Reha Kavas

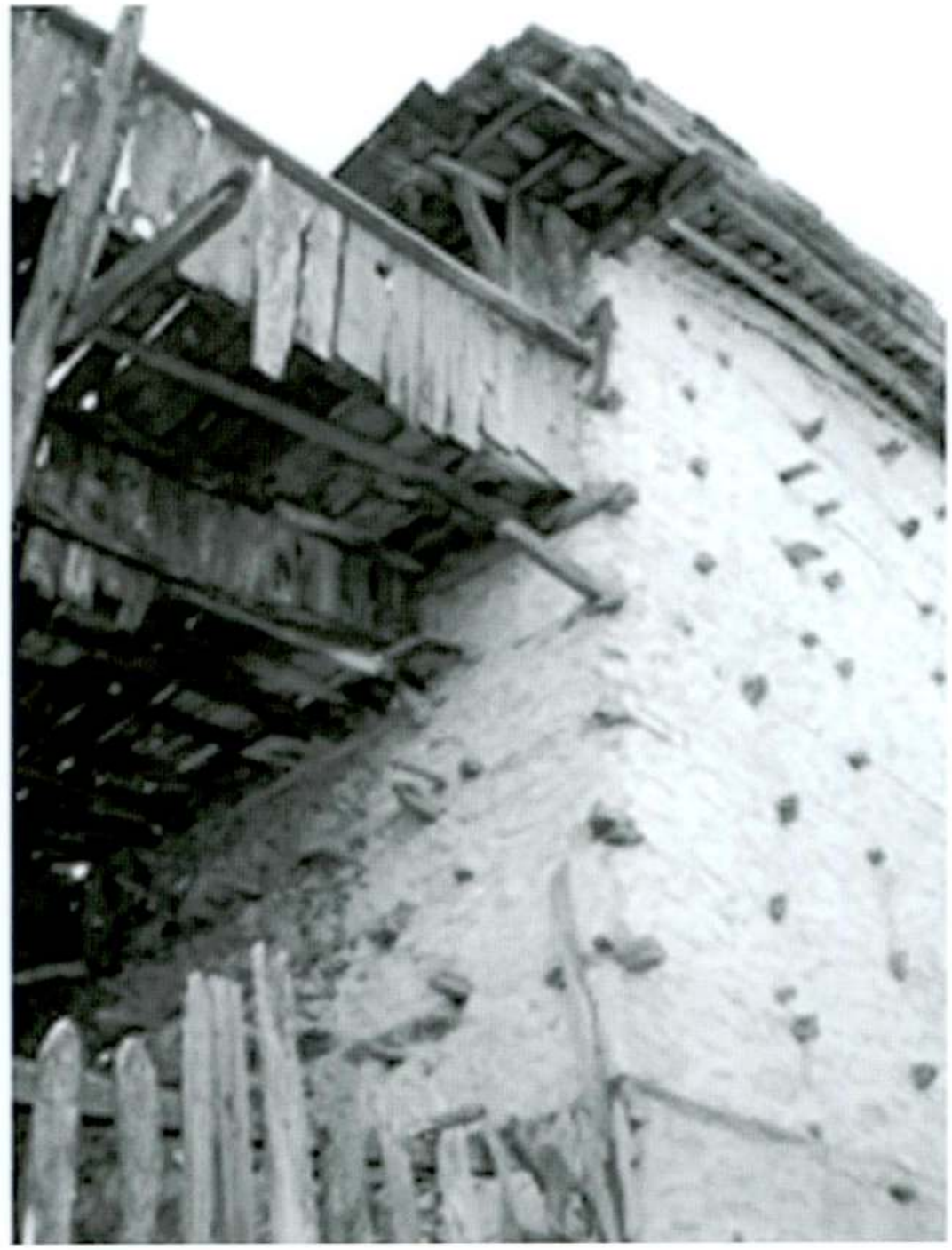

Şekil 17 - Fiziksel Kurgu: Ürünlü Köyü (İbradı-Antalya) Orta Mahalle'de bir geleneksel konut (fotoğraf: K.R. Kavas) 


\section{Kemal Reha Kavas}

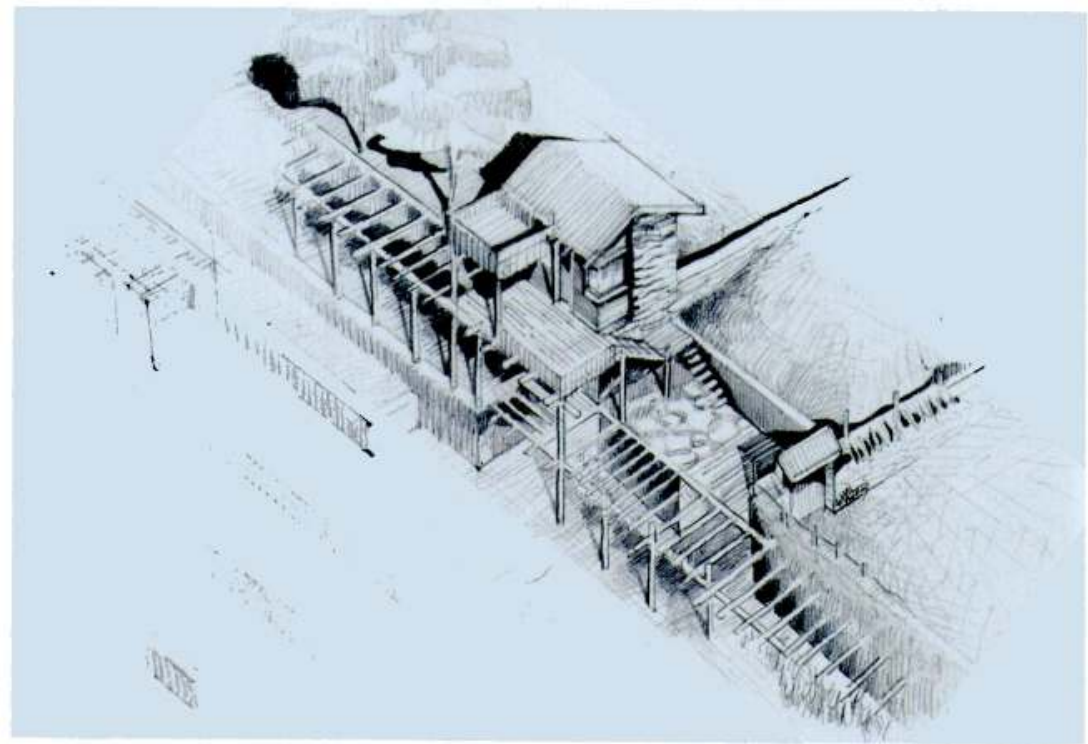

Şekil 18 - Batı Toroslar'da çevre ile bütünleşik tipik bir bağ evi, Akseki - İbradı Havzası, Antalya (çizim: K.R. Kavas) 